\title{
The North Brazil Undercurrent
}

\author{
LOTHAR STRAMMA, ${ }^{*}$ JÜRGEN FISCHER* and JÖRG REPPIN*
}

(Received 2 November 1993; in revised form 19 July 1994; accepted 19 August 1994)

\begin{abstract}
The flow field in the area of what was thought to be the source region of the North Brazil Current (NBC) off the northeast coast of Brazil between $5^{\circ} 30^{\prime} \mathrm{S}$ and $10^{\circ} \mathrm{S}$ was investigated in austral spring during November 1992 and compared with observations in October 1990. The data were taken with several different instruments, including vessel-mounted ADCP, lowered-ADCP, Pegasus, CTD and XBTs. The flow was found off the coast at $5^{\circ} 30^{\prime} \mathrm{S}$ as well as at $10^{\circ} \mathrm{S}$ as an undercurrent, the North Brazil Undercurrent (NBUC). The NBUC shows a subsurface core at about $200 \mathrm{~m}$ depth with velocities of up to $90.0 \mathrm{~cm} \mathrm{~s}^{-1}$, resulting in large northward transports of more than $22 \mathrm{~Sv}$ in the upper $1000 \mathrm{~m}$. The transport is about the same at $5^{\circ} 30^{\prime} \mathrm{S}$ and $10^{\circ} \mathrm{S}$, hence no net inflow from the east is required to feed the NBUC. The climatological Ekman transport is to the south between $5^{\circ} 30^{\prime} \mathrm{S}$ and $10^{\circ} \mathrm{S}$, and in consequence the northward flow near the surface was reduced and might be one reason for the existence of the undercurrent. The flow near the coast was to the north at $10^{\circ} \mathrm{S}$, therefore the Brazil Current had to start as a coastal current south of $10^{\circ} \mathrm{S}$. For the zonal sections at $5^{\circ} 30^{\prime} \mathrm{S}$ and $10^{\circ} \mathrm{S}$ the geostrophic computations relative to the density surface $\sigma_{1}$ $=32.15 \mathrm{~kg} \mathrm{~m}^{-3}$ (about $1150 \mathrm{~m}$ depth) resulted in transports comparable to those obtained from direct measurements. The results further show that the choice of a correct level of no motion can be supported by the direct observations. A shallower reference based on water mass boundaries alone would reduce the NBUC transport to almost zero. Computations with data from the historical data base for austral fall resulted in a weaker NBUC of less than $20 \mathrm{~Sv}$ near $10^{\circ} \mathrm{S}$, indicating a possible seasonal signal in the NBUC with a stronger NBUC in austral spring.
\end{abstract}

\section{INTRODUCTION}

In the literature there is not much information on the formation region of the North Brazil Current (NBC) south of $5^{\circ} \mathrm{S}$. Near the northeast coast of Brazil the South Equatorial Current (SEC) is described as splitting into the southward flowing Brazil Current and the northwestward flowing $\mathrm{NBC}$, as can be seen from the schematic flow field presented by Richardson et al. (1994). Stramma et al. (1990) described near $15^{\circ} \mathrm{S}$ a northwestward flow of $8 \mathrm{~Sv}$ ( 1 Sverdrup $=10^{6} \mathrm{~m}^{3} \mathrm{~s}^{-1}$ ) crossing $30^{\circ} \mathrm{W}$. In February and March the southern part of the SEC reaches the shelf near $10^{\circ} \mathrm{S}$, and about $4 \mathrm{~Sv}$ continues towards the northwest into the NBC. Another branch, is also carrying $4 \mathrm{~Sv}$, turns southward as the beginning of the Brazil Current. At $30^{\circ} \mathrm{W}$ another westward flow of approximately 8-10 Sv enters the area near $10^{\circ} \mathrm{S}$ and not only strengthens the NBC (Stramma et al., 1990) but also contributes to the South Equatorial Countercurrent (SECC), which is sometimes observed between $7^{\circ} \mathrm{S}$ and $9^{\circ} \mathrm{S}$ (Molinari, 1983). A second eastward flowing current band observed south of the equator is the South Equatorial Undercurrent (SEUC) at about $3^{\circ} \mathrm{S}$

\footnotetext{
*Institut für Meereskunde an der Universität Kiel, Düsternbrooker Weg 20, 24105 Kiel, Germany.
} 
to $5^{\circ} \mathrm{S}$ (Molinari, 1982). The transport distribution (Stramma et al., 1990) near $10^{\circ} \mathrm{S}$ was based on data from February and March, and, as will be shown later, the reference level used was probably not the best choice.

Surface drifters drogued at $15 \mathrm{~m}$ depth deployed during Meteor cruise 14 in October 1990 at about $33^{\circ} \mathrm{W}$ between $6^{\circ} \mathrm{S}$ and $9^{\circ} \mathrm{S}$ all turned to the south near the coast (W. Krauss, pers. comm.). Ship drift data have long shown the Brazil Current originating in the bifurcation of the SEC near Cabo de Sao Roque (530'S) (Rennell, 1832), a feature that also can be seen in the trajectories of satellite-tracked drifting buoys (Molinari, 1983; Reverdin and McPhaden, 1986). However, the initial southward drift near Cabo de Sao Roque is probably only the Ekman layer, which has the same southward motion (Richardson and Walsh, 1986; Arnault, 1987) observed by the drifters; there seems to be no southward geostrophic surface current north of $10^{\circ} \mathrm{S}$ (Arnault, 1987), although Reid's (1989) map of adjusted steric height at $0 \mathrm{db}$ showed a southward flow at the Brazilian coast at $9^{\circ} \mathrm{S}$, while the southward component for the adjusted steric height of $250 \mathrm{db}$ was located south of $20^{\circ}$ S (Reid, 1989; Reid, 1994).

Until now, few details have been known about the source region of the NBC or about possible seasonal signals in the flow field, Data from different instruments on two cruises with R.V. Meteor, in October 1990 and November 1992, are used here (a) to investigate whether the splitting of the SEC happens north of $10^{\circ} \mathrm{S}$ in austral spring, (b) to describe, from closed boxes, the transports in the "source region of the North Brazil Current" and (c) to look for indications of a seasonal signal by comparing the transports at $5^{\circ} 30^{\prime} \mathrm{S}$ and $10^{\circ} \mathrm{S}$ with the transports of sections from the historical data base and a section at $5^{\circ} 30^{\prime} \mathrm{S}$ done by R.V. Meteor in June 1991.

\section{TIIE DATA}

The cruise tracks and CTD station locations between $5^{\circ} \mathrm{S}$ and $10^{\circ} \mathrm{S}$ east of the Brazilian coast from Meteor cruise M14-2 (October 1990) and Meteor cruise M22-2 (November 1992) are shown in Fig. 1. Although the sections from both cruises at around $5^{\circ} \mathrm{S}$ are located between $5^{\circ} 30^{\prime} \mathrm{S}$ and $5^{\circ} 00^{\prime} \mathrm{S}$, in the following text the sections are referred to as being $5^{\circ} 30^{\prime} \mathrm{S}$ as the strong current band was crossed at $5^{\circ} 30^{\prime} \mathrm{S}$. For a comparison at $5^{\circ} 30^{\prime} \mathrm{S}$ another section at $5^{\circ} 30^{\prime} \mathrm{S}$ is available from Meteor cruise M16-3 in June 1991.

In October $199010 \mathrm{CTD}$ stations were made at $5^{\circ} 30^{\prime} \mathrm{S}$ between the coast and $32^{\circ} 32^{\prime} \mathrm{W}$. For the box along about $33^{\circ} \mathrm{W}$ and $9^{\circ} 30^{\prime} \mathrm{S}$ (in the following referred to as $9^{\circ} \mathrm{S}$ ) no time for CTD stations was left. Along these two sections in total 25 XBTs were deployed. The vessel-mounted ADCP (VM-ADCP) operated along all three sections and collected the velocity distribution for the upper 0 to $180-200 \mathrm{~m}$. An ADCP was mounted to the CTDrosette and lowered with the CTD (in the following named IADCP) to measure a continuous velocity profile. In 1990 only three IADCP profiles were obtained near the coast at $5^{\circ} 30^{\prime} \mathrm{S}$.

In November 1992 the IADCP worked on all CTD stations of the box except for two stations in the center of the $5^{\circ} 30^{\prime} \mathrm{S}$ section. At $5^{\circ} 30^{\prime} \mathrm{S}$ eight Pegasus profiles were made between the shelf and $31^{\circ} 30^{\prime} \mathrm{W}$. In total $15 \mathrm{CTD}$ stations were made along $5^{\circ} 30^{\prime} \mathrm{S}$ between the coast and $30^{\circ} \mathrm{W}$, four stations between the $5^{\circ} 30^{\prime} \mathrm{S}$ and $10^{\circ} \mathrm{S}$ section and 10 stations along the $10^{\circ} \mathrm{S}$ section between the coast and $32^{\circ} 30^{\prime} \mathrm{W}$ (Fig. 1). Along the entire box the VMADCP sampled the upper ocean velocity data. The VM-ADCP was installed in the hydrographic well, and the measurcment range varied between 270 and $400 \mathrm{~m}$ depth. 


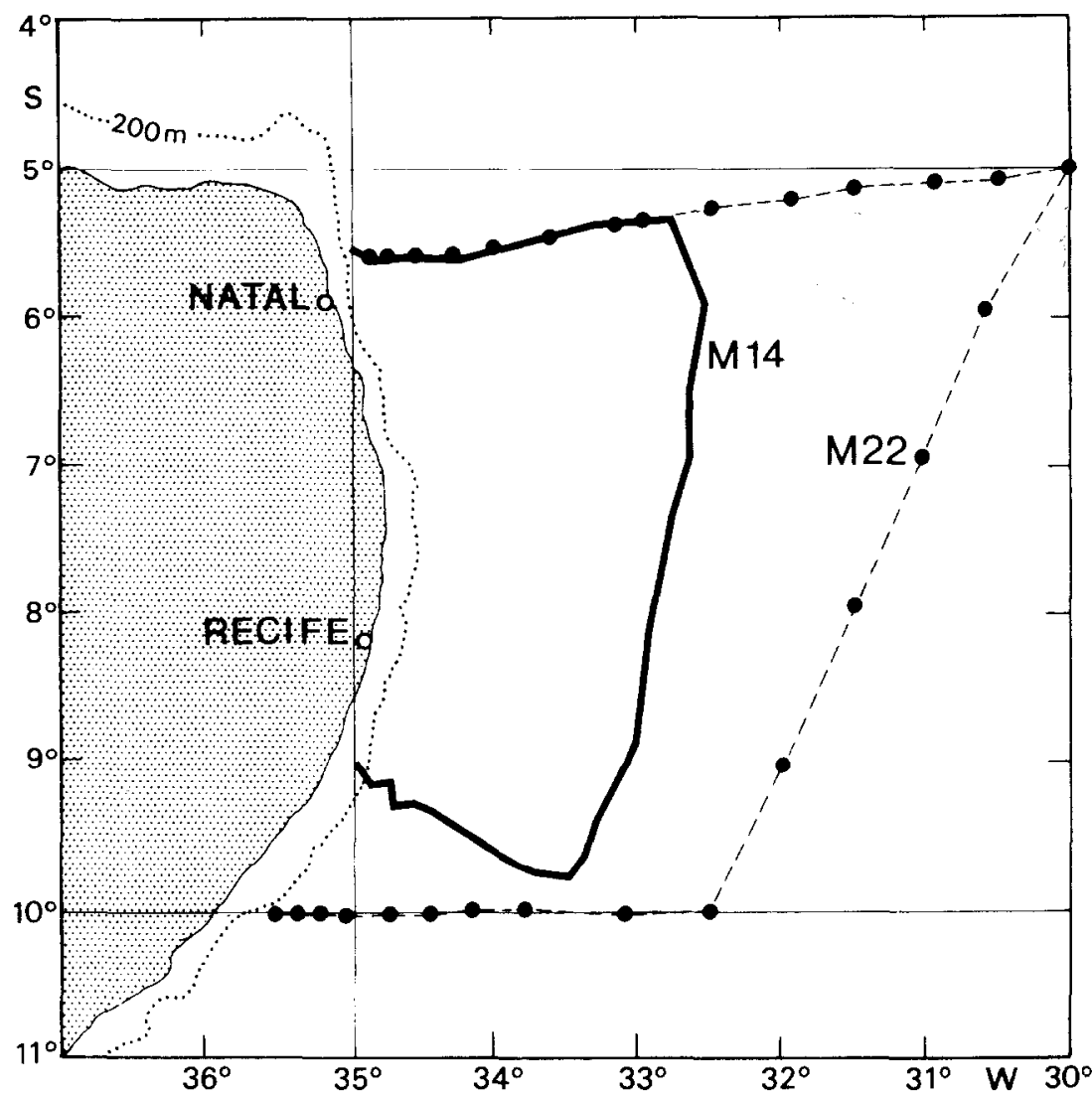

Fig. 1. Cruise tracks (lines) with VM-ADCP measurements off the northeast coast of Brazil for Meteor cruise M14-2 (M14) in October 1990 and M22-2 (M22) in November 1992 with station locations as dots. Included is the $200 \mathrm{~m}$ depth contour.

\section{METHODS}

During Meteor cruise M14 in October 1990, a self-contained ADCP mounted in the hydrographic well had to be used because of defective transducers in the built-in vesselmounted ADCP. Exlernal heading and navigation from the ship's central data recording system were used to correct the averaged profiles for heading and speed over ground. Due to the lower source level of the self-contained $150 \mathrm{kHz}$ ADCP compared with a normal VM-ADCP, the measurement range was restricted to the upper 180-200 $\mathrm{m}$ depth. The data were calibrated with respect to the alignment angle of the transducers and interpolated to a regular grid of $10 \mathrm{~m}$ vertically and $0.1^{\circ}(10 \mathrm{~km})$ horizontally using a Gaussian weighting function with a cut-off radius of $20 \mathrm{~m}$ and $0.2^{\circ}$, respectively. During the cruise in November 1992 (M22), a $150 \mathrm{kIIz}$ VM-ADCP was used. The measurement range varied between $270 \mathrm{~m}$ and $400 \mathrm{~m}$ depth depending on the amount of scatterers in the upper ocean. Unfortunately a defect in one synchro-converter led to course dependent heading offsets of up to 10 degrees. However, within the ensemble interval $(5 \mathrm{~min})$ the heading variations were small, and it was therefore possible to correct the $5 \mathrm{~min}$ averages with external heading measurements. Periods with heading variations larger than a few degrees were 
omitted; these occurred during the deceleration and acceleration phases before and after each station. After this correction the same calibration and interpolation procedure as for M14 was applied. Remaining uncertainties due to the heading and GPS errors together with the short time inaccuracies of the ADCP were estimated to be of up to $10 \mathrm{~cm} \mathrm{~s}^{-1}$. But since these errors are mostly random, they will be reduced when integrating over many ensembles. By the regridding procedure, i.e. smoothing over about $20 \mathrm{~km}$, corresponding to 12 ensembles, the error of the interpolated data was reduced to $3 \mathrm{~cm} \mathrm{~s}^{-1}$. For transport calculations, e.g. over the width (100 km) of the North Brazil Undercurrent (NBUC) and $250 \mathrm{~m}$ depth, the uncertainty was estimated to be less than \pm 1 Sv. As the VM-ADCP does not resolve the upper few meters of the ocean, the shears were extrapolated from the uppermost two bins to the surface for velocity and transport calculations.

In addition to the VM-ADCP, direct observations of the deeper velocity field were obtained by an acoustic dropsonde, the Pegasus (Spain et al., 1981), which was used on several stations along $5^{\circ} 30^{\prime} \mathrm{S}$, and by lowering an ADCP (IADCP) with the CTD (Fischer and Visbeck, 1993). Both methods compare reasonably well, and the estimated errors of the 1ADCP (order $5 \mathrm{~cm} \mathrm{~s}^{-1}$ ) are a little larger than those of Pegasus profiles (Send, 1994).

The IADCP was exchanged due to a broken transducer at the $5^{\circ} 30^{\prime} \mathrm{S}$ section in November 1992, and the new "broad-band" ADCP was an untested device which showed large data gaps on the upward casts, but only during casts which exceeded $2000 \mathrm{~m}$. However, the downward casts could be used on those stations to determine relative velocity profiles which were then referenced by the VM-ADCP on the same station by minimizing the mean between the IADCP and VM-ADCP velocity differences in the depth range $50-250 \mathrm{~m}$. This was done for all stations west of $34^{\circ} \mathrm{W}$ or the $5^{\circ} 30^{\prime} \mathrm{S}$ section and all stations along $10^{\circ} \mathrm{S}$.

Based on the assumption that the flow field was resolved by the station grid (which was not the case on the diagonal section between $5^{\circ} \mathrm{S}$ and $10^{\circ} \mathrm{S}$ ), and that the 1ADCP errors of 5 $\mathrm{cm} \mathrm{s}^{-1}$ were random from station to station, the estimated transport uncertainty for the six stations across the $1000 \mathrm{~m}$ deep North Brazil Undercurrent would be of the order of $\pm 2 \mathrm{~Sv}$.

The calibration of the CTD data resulted in accuracies of $0.002^{\circ} \mathrm{C}$ in temperature, 0.003 in salinity and $3 \mathrm{dbar}$ in pressure. The CTD data were used to calculate geostrophic velocities and transports. For geostrophic computations a reference depth is needed to convert from relative to absolute velocities. Based on an investigation of the water mass distribution and the knowledge of the spreading directions of the different water masses, Stramma (1991) used a reference depth of $\sigma_{1}=32.15 \mathrm{~kg} \mathrm{~m}^{-3}$ for an investigation of the SEC in the Atlantic. This density layer is located at a depth of about $1150 \mathrm{~m}$ and represents the boundary between the bottom of the northward flowing upper branch of Circumpolar Deep Water and the top of the southward flow of Upper North Atlantic Deep Water. In the following the density $\sigma_{1}=32.15 \mathrm{~kg} \mathrm{~m}^{-3}$ was used as the reference depth for the geostrophic calculations.

The depth of the $1.8^{\circ} \mathrm{C}$ potential temperature was described by Molinari et al. (1992) as the lower boundary of the deeper NADW layer. This isotherm could be another possible reference level for geostrophic computations (Rhein et al., 1995). The $1.8^{\circ} \mathrm{C}$ isotherm was found between $3680 \mathrm{~m}$ depth near the South American continent and $3900 \mathrm{~m}$ further offshore. It indicates the boundary between the lower North Atlantic Deep Water (INADW) and the Antarctic Bottom Water (AABW) and coincides roughly with the density surface $\sigma_{4}=45.90 \mathrm{~kg} \mathrm{~m}^{-3}$. As this density surface is far away from the layer investigated, we prefer to use the reference level closer to the investigated layer. As will be 
shown later, the deeper reference level led to differences in the details of the geostrophic current fields compared to the direct observations, while currents calculated relative to the density $\sigma_{1}=32.15 \mathrm{~kg} \mathrm{~m}^{-3}$ compare much better with the direct velocity observations.

\section{SECTION AT $5^{\circ} \mathrm{S}$}

\section{Vessel-mounted ADCP}

The velocity distribution in the upper ocean from the VM-ADCP in November 1992 is presented in Fig. $2 \mathrm{a}-\mathrm{d}$. The northward velocity component at $5^{\circ} 30^{\prime} \mathrm{S}$ (Fig. 2a) shows that the flow was located near the coast with velocities exceeding $80 \mathrm{~cm} \mathrm{~s}^{-1}$. The core of current is found around $200 \mathrm{~m}$ depth with most of the current sheared away towards the surface; thus the flow field has the structure of an undercurrent, the North Brazil Undercurrent. The zonal component near the coast at $5^{\circ} 30^{\prime} \mathrm{S}$ showed only weak westward velocities of 10 $\mathrm{cm} \mathrm{s}^{-1}$ in 100-200 m depth due to the nearly meridional shelf (therefore not shown). While the NBUC reached its maximum speed at $200 \mathrm{~m}$ depth, the velocity at the sea surface was reduced to about $20 \mathrm{~cm} \mathrm{~s}^{-1}$ northward. The major northward flow of the NBUC was found west of $34^{\circ} \mathrm{W}$, while between $31^{\circ} \mathrm{W}$ and $34^{\circ} \mathrm{W}$ only weak southward velocities were observed. An eastward extension of the NBUC was observed at about $150 \mathrm{~m}$ depth. It appeared as a $70 \mathrm{~km}$ long and only about $100 \mathrm{~m}$ thick velocity tongue with more than $10 \mathrm{~cm}$ $\mathrm{s}^{-1}$. In October 1990 the VM-ADCP section at $5^{\circ} 30^{\prime} \mathrm{S}$ (Fig. 3a) also showed a northward subsurface-current maximum of more than $90 \mathrm{~cm} \mathrm{~s}^{-1}$, and as was the structure found in November 1992, the eastward extending velocity tongue was found at about $150 \mathrm{~m}$ depth. Due to the limited vertical range $(200 \mathrm{~m})$, the core of the NBUC was not completely resolved.

\section{Lowered ADCP}

The deeper reaching flow in November 1992 (surface to $1200 \mathrm{~m}$ depth) was measured by the IADCP (Fig. 4a). For the upper layer (0-250 m) this data set compared well with the VM-ADCP velocities (Fig. 2a). East of $34^{\circ} \mathrm{W}$ the $1 \mathrm{ADCP}$ data were adjusted to the VMADCP and an independent comparison was not possible. Below the current core at $200 \mathrm{~m}$ depth the currents were sheared to $40 \mathrm{~cm} \mathrm{~s}^{-1}$ near $500 \mathrm{~m}$, and with weaker shears below $500 \mathrm{~m}$ the NBUC was still visible in $1000 \mathrm{~m}$ depth. Between $31^{\circ} \mathrm{W}$ and $34^{\circ} \mathrm{W}$ weak southward flow of $10 \mathrm{~cm} \mathrm{~s}^{-1}$ or less was observed, and between $30^{\circ} \mathrm{W}$ and $31^{\circ} \mathrm{W}$ a fairly deep reaching band of northward flow of up to $20 \mathrm{~cm} \mathrm{~s}^{-1}$ was found in November 1992 .

\section{Geostrophic calculations}

Geostrophic velocities for November 1992 (M22) were calculated relative to the depth of the isopycnal $\sigma_{1}=32.15 \mathrm{~kg} \mathrm{~m}^{-3}$ which varies between $1130 \mathrm{~m}$ and $1190 \mathrm{~m}$ (Fig. 4b). The general structure of the geostrophic flow field (Fig. 4b) is quite similar to the direct current observations with respect to amplitude and extent of the NBUC. However, the geostrophic velocity field showed higher variability in the upper $100 \mathrm{~m}$ of the ocean. East of the NBUC southward flow is found between $400 \mathrm{~m}$ and $1100 \mathrm{~m}$ with velocities up to $10 \mathrm{~cm} \mathrm{~s}^{-1}$, which is also present but a little weaker in the IADCP data. On the eastern side of the section between $30^{\circ} \mathrm{W}$ and $31^{\circ} \mathrm{W}$, northward flow is found in both representations, but more intense in the IADCP data between the surface and $800 \mathrm{~m}$ depth. 

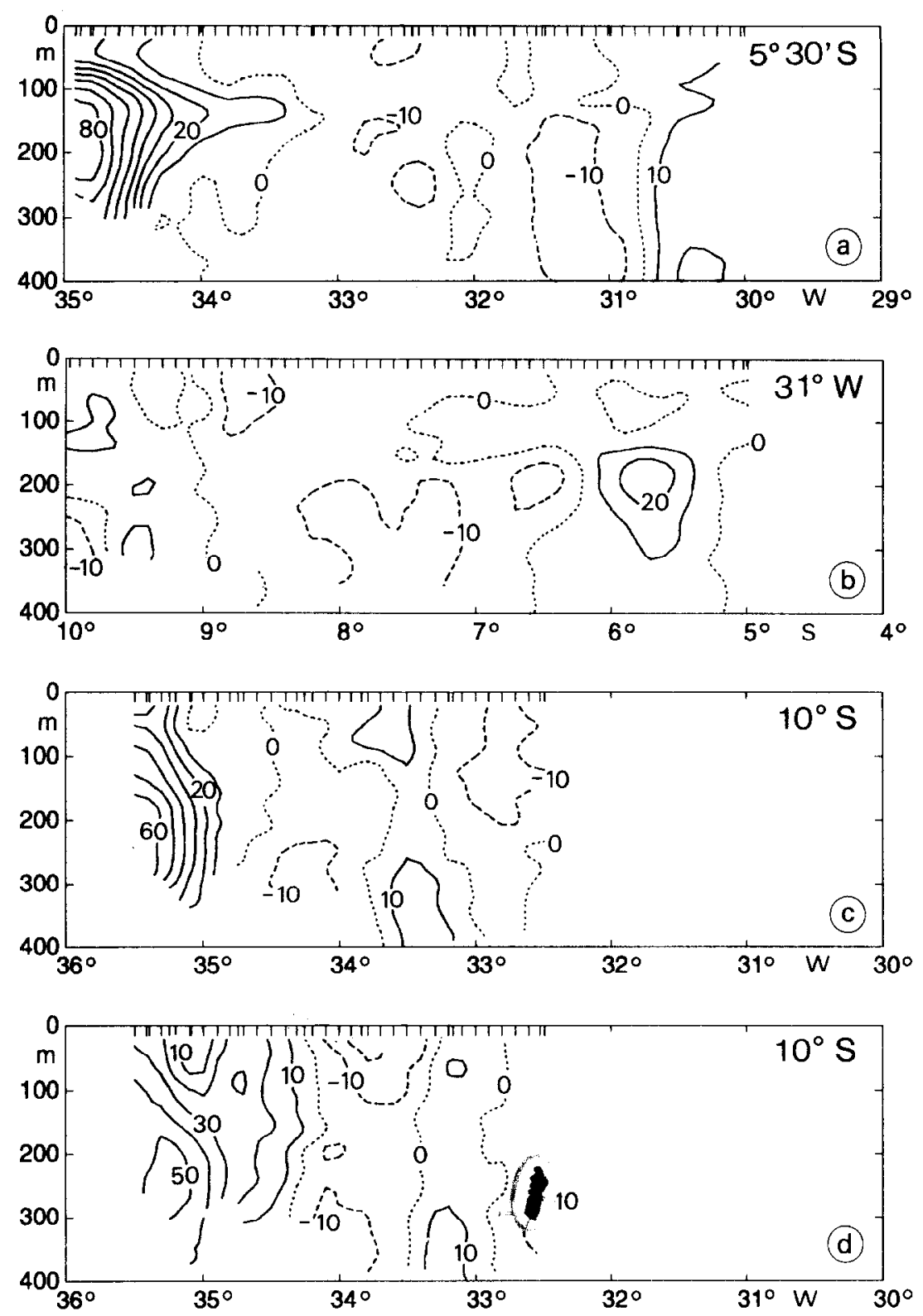

Fig. 2. VM-ADCP velocity in $\mathrm{cm} \mathrm{s}^{-1}$ in November 1992 for (a) the northward component at $5^{\circ} 30^{\prime} \mathrm{S}$, (b) perpendicular to the cruise track at $31^{\circ} \mathrm{W}$ (positive northwestward), (c) the eastward component at $10^{\circ} \mathrm{S}$ and (d) the northward component at $10^{\circ} \mathrm{S}$. The zero velocity is dotted; negative values are dashed lines with $10 \mathrm{~cm} \mathrm{~s}^{-1}$ contour intervals.

For October 1990 the structure of the geostrophic velocity field relative to $\sigma_{1}=32.15 \mathrm{~kg}$ $\mathrm{m}^{-3}$ at $5^{\circ} 30^{\prime} \mathrm{S}$ (Fig. 4c) is comparable to the velocity distribution in November 1992. As in November 1992 a southward flow at about $300-1100 \mathrm{~m}$ was observed in October 1990. The northward flowing NBUC with a subsurface velocity maximum was again found near the 

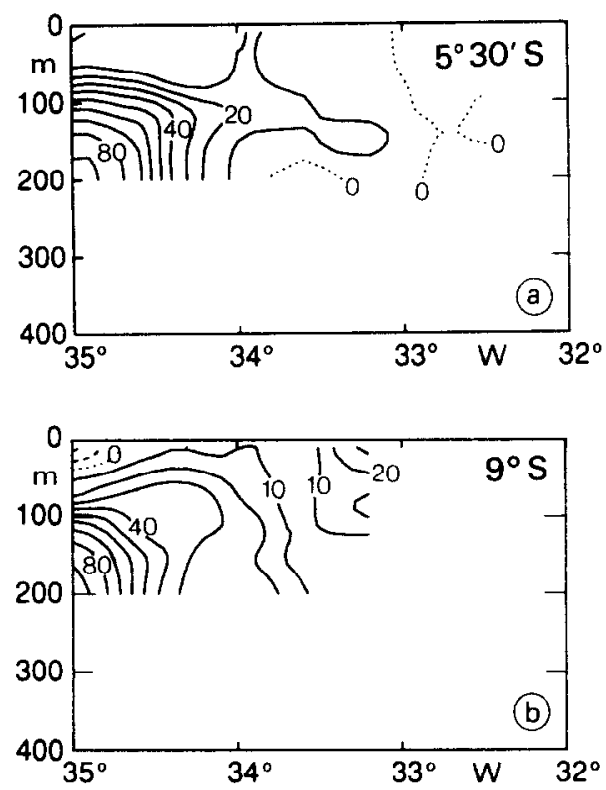

Fig. 3. VM-ADCP velocity in $\mathrm{cm} \mathrm{s}^{-1}$ in October 1990 for northward component at (a) $5^{\circ} 30^{\prime} \mathrm{S}$ and (b) $9^{\circ} \mathrm{S}$.

coast. The northward transport in the upper ocean was found west of $33^{\circ} 30^{\prime} \mathrm{W}$ in October 1990 and the highest velocities of the NBUC were observed west of $34^{\circ} 15^{\prime} \mathrm{W}$. One CTD station was omitted which led to a maximum velocity at $200 \mathrm{~m}$ of $180 \mathrm{~cm} \mathrm{~s}^{-1}$, probably caused by the short station spacing of $10 \mathrm{~km}$ for the station pair. One of the three lADCP profiles taken in the NBUC region showed maximum velocities of $100 \mathrm{~cm} \mathrm{~s}^{-1}$ at $180-300 \mathrm{~m}$ in October 1990, while the VM-ADCP showed maximum velocities of $90 \mathrm{~cm} \mathrm{~s}^{-1}$ at $180 \mathrm{~m}$ depth (Fig. 3a). The geostrophic velocity without the omitted profile (Fig. 4c) showed a value of $100 \mathrm{~cm} \mathrm{~s}^{-1}$ in the core of the NBUC and therefore agreed with the direct measurements. As the eliminated station was not an end-point of the section, the one profile in question has no influence on the transport computations.

Table 1(a) shows the gcostrophic transport at $5^{\circ} 30^{\prime} \mathrm{S}$ for the layers across the entire section in October 1990 and November 1992. The total section transports are quite similar for both cruises. To investigate the geostrophic transports of the western boundary current off the coast, the transports from the coast to the location where a flow reversal appeared were calculated for October 1990 and November 1992 (Table 1(a)). The northward transport at $5^{\circ} 30^{\prime} \mathrm{S}$ in October 1990 summed up to $31.9 \mathrm{~Sv}$ and in November 1992 to $24.2 \mathrm{~Sv}$ in the upper $1000 \mathrm{~m}$. With the deeper reference $\sigma_{4}=45.90 \mathrm{~kg} \mathrm{~m}^{-3}$, transports out to flow reversal were reduced to $28.9 \mathrm{~Sv}$; i.e. there is a $4 \mathrm{~Sv}$ uncertainty in using different reference levels. In October 1990 the NBUC transport was larger than in November 1992, but a stronger southward component east of the NBUC led to the similar transports for the entire section in both cruises.

\section{DIAGONAL SECTION AT $31^{\circ} \mathrm{W}$}

The westward flow across $31^{\circ} \mathrm{W}$ from VM-ADCP was quite weak in November 1992 . The flow perpendicular to the ship section (Fig. 2b) was northwestward between $5^{\circ} \mathrm{S}$ and 

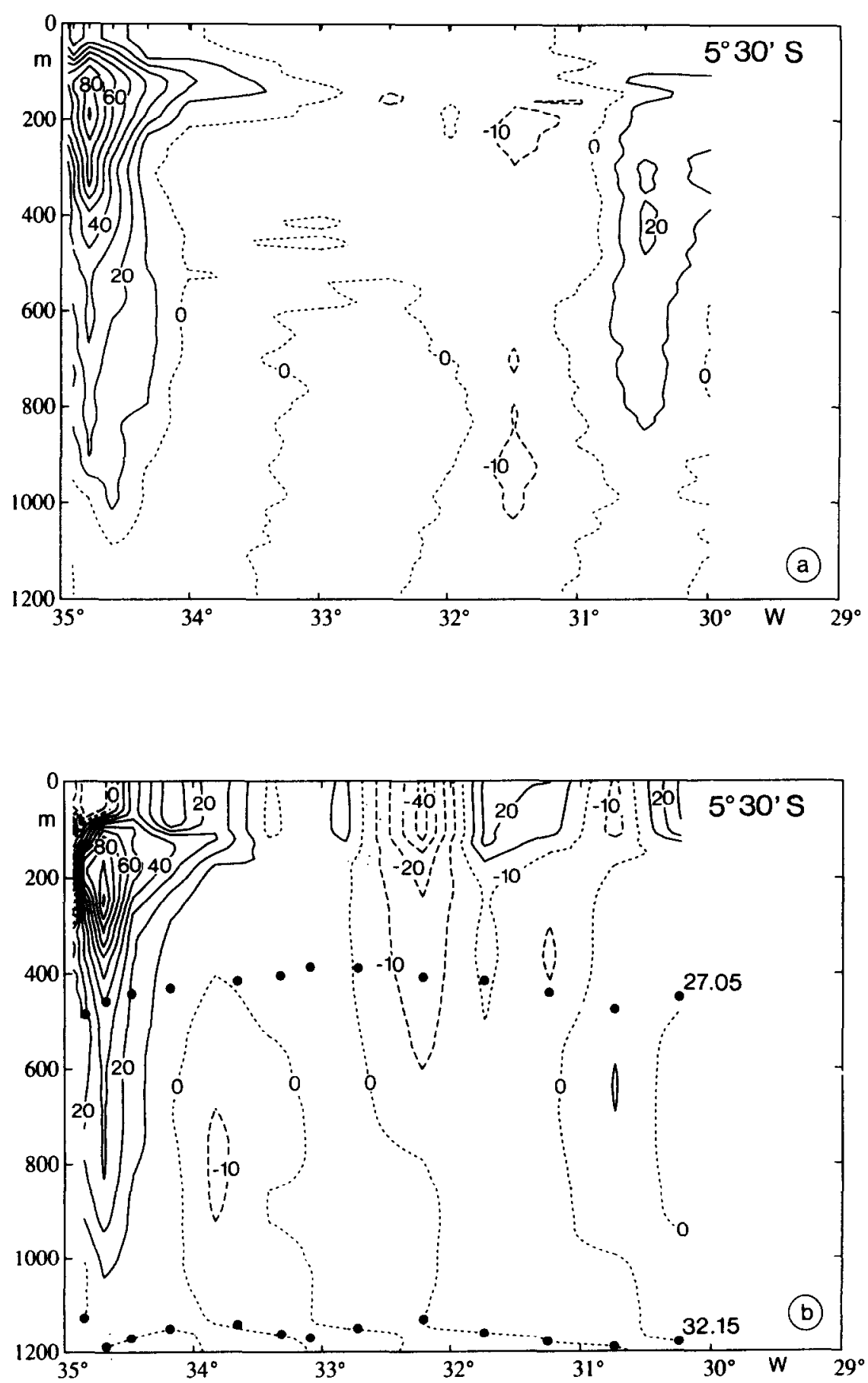

Fig. 4. Velocity in $\mathrm{cm} \mathrm{s}^{-1}$ for the northward component at $5^{\circ} 30^{\prime} \mathrm{S}$ for (a) lowered-ADCP in November 1992, (b) geostrophic velocity relative to $\sigma_{1}=32.15 \mathrm{~kg} \mathrm{~m}^{-3}$ in November 1992 and (c) geostrophic velocity relative to $\sigma_{1}=32.15 \mathrm{~kg} \mathrm{~m}^{-3}$ in October 1990 . The depths of the densities $\sigma_{0}=27.05 \mathrm{~kg} \mathrm{~m}^{3}$ and $\sigma_{1}=32.15 \mathrm{~kg} \mathrm{~m}^{-3}$ are included as dots in (b). 


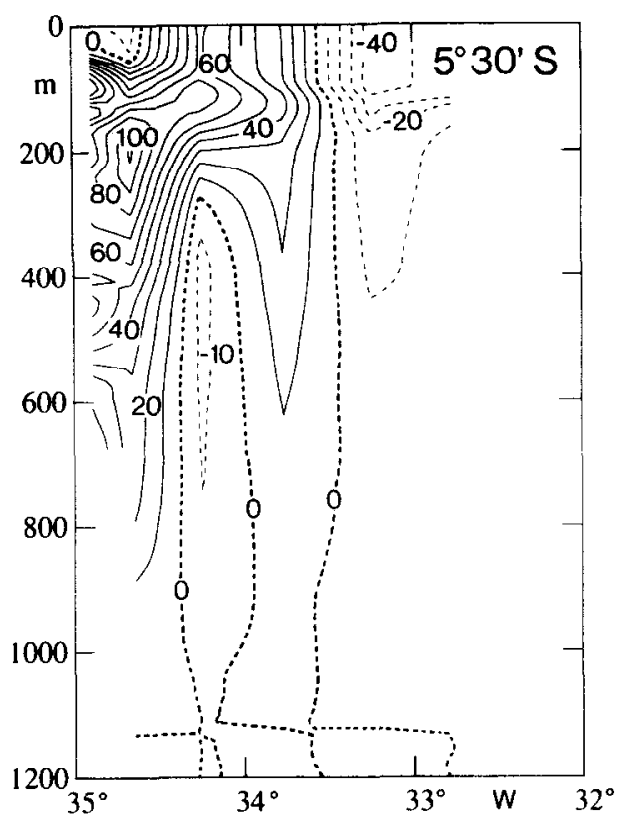

Fig. 4. (Continued)

Table 1. Geostrophic transports at (a) about $5^{\circ} 30^{\prime} \mathrm{S}$ relative to $\sigma_{1}=32.15 \mathrm{~kg} \mathrm{~m}^{-3}$. Positive transport is to the north. The total and near coast transport at $10^{\circ} \mathrm{S}$ is given in $(b)$. The flow reversal is the location where the velocity field changed the flow direction. For comparison the LADCP transport out to the longitude of the flow reversal is shown in the last column

\begin{tabular}{|c|c|c|c|c|c|}
\hline \multirow{2}{*}{$\begin{array}{l}\text { (a) } 5^{\circ} 30^{\prime} \mathrm{S} \\
\text { Depth layer }\end{array}$} & \multicolumn{2}{|c|}{ Entire section } & \multicolumn{2}{|c|}{ Coast to reversal } & \multirow[b]{2}{*}{$\begin{array}{c}\text { Nov } 92 \\
\text { IADCP } \\
\text { to flow-reversal }\end{array}$} \\
\hline & $\begin{array}{c}\text { Oct. } 90 \\
\text { between } 34^{\circ} 56^{\prime} \\
\text { and } 32^{\circ} 32^{\prime} \mathrm{W}\end{array}$ & $\begin{array}{c}\text { Nov. } 92 \\
\text { between } 34^{\circ} 57^{\prime} \\
\text { and } 30^{\circ} 00^{\prime} \mathrm{W}\end{array}$ & $\begin{array}{c}\text { Oct. } 90 \\
\text { between } 34^{\circ} 56^{\prime} \\
\text { and } 33^{\circ} 30^{\prime} \mathrm{W}\end{array}$ & $\begin{array}{c}\text { Nov. } 92 \\
\text { between } 34^{\circ} 57^{\prime} \\
\text { and } 32^{\circ} 27^{\prime} \mathrm{W}\end{array}$ & \\
\hline $0-100 \mathrm{~m}$ & 1.2 & 3.8 & 5.5 & 2.9 & 1.7 \\
\hline $0-250 \mathrm{~m}$ & 9.9 & 12.0 & 17.2 & 12.3 & 7.8 \\
\hline $0-500 \mathrm{~m}$ & 17.1 & 17.0 & 27.0 & 19.3 & 12.7 \\
\hline $0-1000 \mathrm{~m}$ & 19.1 & 20.2 & 31.9 & 24.2 & 16.7 \\
\hline
\end{tabular}

(b) $10^{\circ} \mathrm{S}$

Depth layer

0-100 m

$0-250 \mathrm{~m}$

$0-500 \mathrm{~m}$

$0-1000 \mathrm{~m}$
Nov. 92

between $35^{\circ} 30^{\prime}$ and $32^{\circ} 30^{\prime} \mathrm{W}$
Nov. 92 between $35^{\circ} 30^{\prime}$ and $34^{\circ} 15^{\prime} \mathrm{W}$
Nov. 92

IADCP

to flow-reversal 
$6^{\circ} 30^{\prime} \mathrm{S}$ and south of $9^{\circ} \mathrm{S}$. Maximum speeds were up to $20 \mathrm{~cm} \mathrm{~s}^{-1}$ at $200 \mathrm{~m}$ depth. Between $6^{\circ} 30^{\prime} \mathrm{S}$ and $9^{\circ} \mathrm{S}$ there was a weak southeastward flow, balancing the total VM-ADCP transport across the section to almost zero. The southeastward flow near $8^{\circ} \mathrm{S}$ is found where the SFCC should be located, and the eastward flow could be the signature of this current.

In October 1990 the diagonal section closing the box was located at about $33^{\circ} \mathrm{W}$ (Fig. 1). The VM-ADCP showed between $5^{\circ} 30^{\prime} \mathrm{S}$ and $8^{\circ} 30^{\prime} \mathrm{S}$ a southwestward flow and between $8^{\circ} 30^{\prime} \mathrm{S}$ and $9^{\circ} 40^{\prime} \mathrm{S}$ a southeastward flow in the upper $200 \mathrm{~m}$. This flow structure led to a net westward transport of $4.2 \mathrm{~Sv}$.

\section{THE $9^{\circ} \mathrm{S}$ AND $10^{\circ} \mathrm{S}$ SECTIONS}

\section{Vessel-mounted ADCP}

The velocity distribution at $10^{\circ} \mathrm{S}$ from the VM-ADCP in November 1992 showed the largest velocities near the coast in both the eastward and northward component (Fig. 2c and $\mathrm{d}$ ) with velocities of about $60 \mathrm{~cm} \mathrm{~s}^{-1}$. At this latitude the Brazilian shelf $(200 \mathrm{~m}$ isobath) is oriented toward about $35^{\circ} \mathrm{T}$ (Fig. 1), and the NBUC followed the topography in the northeastward direction. Alongshore speeds associated with the NBUC showed velocities of up to $90 \mathrm{~cm} \mathrm{~s}^{-1}$ similar to what was found farther north. Another similarity between the two scctions was the subsurface velocity core at about $200 \mathrm{~m}$ depth with weaker northeastward velocities closer to the sea surface. The strong flow was again restricted to the coast while to the east of the NBUC the currents were weak.

The VM-ADCP section at $9^{\circ} \mathrm{S}$ in October 1990 (Fig. 3) showed a northward subsurfacecurrent maximum of more than $90 \mathrm{~cm} \mathrm{~s}^{-1}$ below $150 \mathrm{~m}$ depth. Towards the surface the current was sheared away to less than $10 \mathrm{~cm} \mathrm{~s}^{1}$; at the westernmost part of the $9^{\circ} \mathrm{S}$ section there was even a southward flow very close to the surface. Horizontally, the NBUC current core extended to about $34^{\circ} \mathrm{W}$, corresponding to about $100 \mathrm{~km}$ width. Northward transports of the top $200 \mathrm{~m}$ out to $34^{\circ} \mathrm{W}$ were similar for the $5^{\circ} 30^{\prime} \mathrm{S}$ and $9^{\circ} \mathrm{S}$ sections, $6.9 \mathrm{~Sv}$ at $5^{\circ} 30^{\prime} \mathrm{S}$ and $7.4 \mathrm{~Sv}$ at $9^{\circ} \mathrm{S}$. The $0.5 \mathrm{~Sv}$ imbalance is within the error bounds. Out to $33^{\circ} 06^{\prime} \mathrm{W}$ (easternmost longitude of the $9^{\circ} \mathrm{S}$ section) the transports were $9.8 \mathrm{~Sv}$ at $9^{\circ} \mathrm{S}$ and $8.4 \mathrm{~Sv}$ at $5^{\circ} 30^{\prime} \mathrm{S}$. At the $9^{\circ} \mathrm{S}$ section the zonal velocity component was small; eastward velocities of $10 \mathrm{~cm} \mathrm{~s}^{-1}$ were found only near the core of the NBUC (east of $34^{\circ} 30^{\prime} \mathrm{W}$ ). Further offshore zonal currents were even smaller. Compared to the sections at $10^{\circ} \mathrm{S}$ in November 1992, where both velocity components contributed about equally, the flow at $9^{\circ} \mathrm{S}$ was predominantly northward, following the topography at this latitude (Fig. 1). Therefore, the NBUC appears to turn from a northeastward direction at $10^{\circ} \mathrm{S}$ to a northward direction at $9^{\circ} \mathrm{S}$, continuing northward to $5^{\circ} 30^{\prime} \mathrm{S}$.

\section{Lowered ADCP}

For better comparison of the flow structure at $5^{\circ} 30^{\prime} \mathrm{S}$ and $10^{\circ} \mathrm{S}$ the lADCP currents at $10^{\circ} \mathrm{S}$ were rotated (by $35^{\circ}$ ) according to the orientation of the topography, and the alongshore components for both sections in November 1992 are shown versus offshore distance (Fig. 5). At both latitudes a subsurface core was observed in about $200 \mathrm{~m}$ depth with maximum velocities of $90 \mathrm{~cm} \mathrm{~s}^{-1}$ at $5^{\circ} 30^{\prime} \mathrm{S}$ and $80 \mathrm{~cm} \mathrm{~s}^{-1}$ at $10^{\circ} \mathrm{S}$. At $10^{\circ} \mathrm{S}$ the NBUC appeared to extend deeper, with the $10 \mathrm{~cm} \mathrm{~s}^{-1}$ isotach reaching almost $1100 \mathrm{~m}$ depth. 

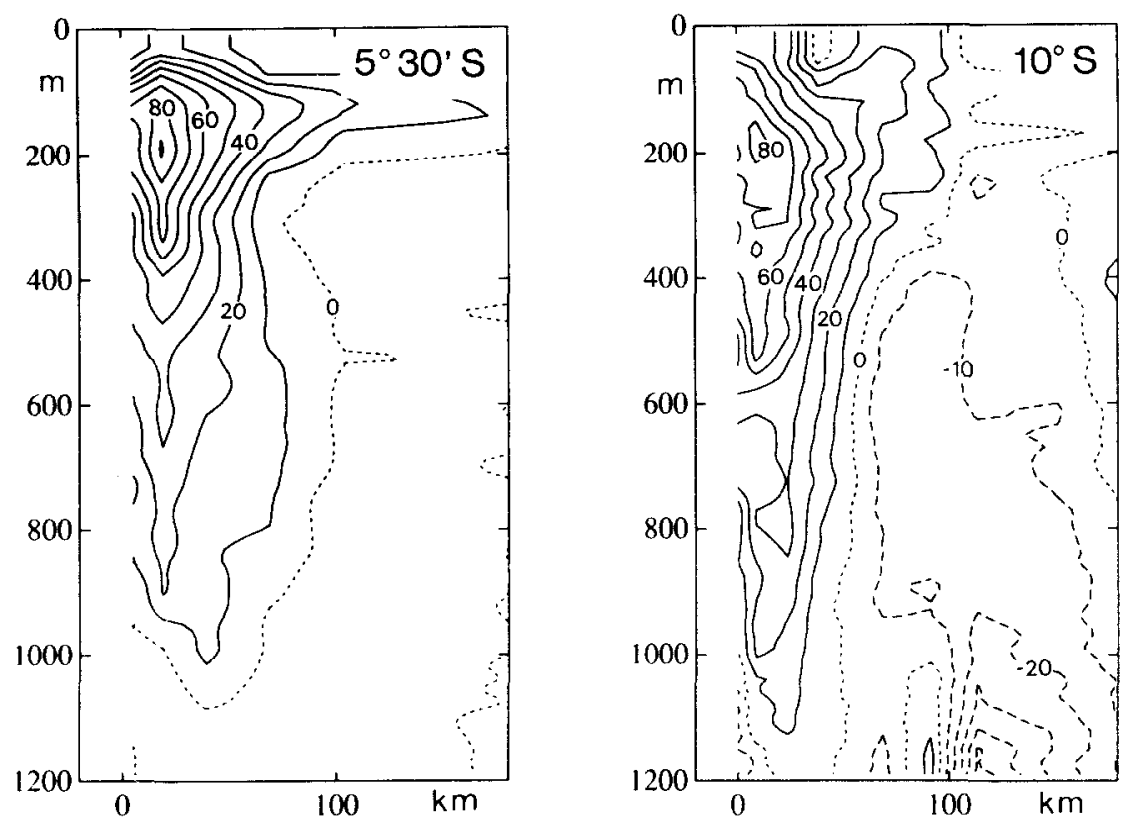

Fig. 5. The North Brazil Undercurrent velocity distribution versus offshelf distance (isolines for $10 \mathrm{~cm} \mathrm{~s}^{-1}$ contour intervals) at $5^{\circ} 30^{\prime} \mathrm{S}$ and $10^{\circ} \mathrm{S}$ in November 1992 from the lowered-ADCP rotated to show the along-shore component.

There was no indication of an eastward extension of the velocity core near $150-200 \mathrm{~m}$ which seemed to be a permanent feature of the flow structure at $5^{\circ} 30^{\prime} \mathrm{S}$ (Fig. 5).

\section{Geostrophic calculations}

Geostrophic transports relative to $\sigma_{1}=32.15 \mathrm{~kg} \mathrm{~m}^{-3}$ (Table $1 \mathrm{~b}$ ) show that at $10^{\circ} \mathrm{S}$ the western boundary current transported $22.2 \mathrm{~Sv}$ northward in the upper $1000 \mathrm{~m}$ west of the flow reversal. Compared with the transport at $5^{\circ} 30^{\prime} \mathrm{S}, 92 \%$ of the geostrophic transport of the NBUC in November 1992 crossed $10^{\circ} \mathrm{S}$, and only a small net contribution of $2 \mathrm{~Sv}$ (within the error margins) was needed to balance the transports between $10^{\circ} \mathrm{S}$ and $5^{\circ} 30^{\prime} \mathrm{S}$. Such a small contribution could be explained by the unresolved flow on the shallow shelf or could be an inflow from the east.

Plots of geostrophic transport versus offshore distance during Meteor cruise 22 show that there were close similarities between the two latitudes from the coast out to the offshore edge of the NBUC. On the offshore side of the NBUC the differences were a little larger, presumably due to the one station at $5^{\circ} 30^{\prime} \mathrm{S}$ that led to a singular transport maximum. Summarizing, the NBUC in November 1992 occurred as a strong subsurface boundary current flowing along the edge of the Brazilian shelf in the latitude range $10^{\circ} \mathrm{S}-5^{\circ} 30^{\prime} \mathrm{S}$ without a larger contribution from the east in that latitude belt. Of the total transport $(0$ $1000 \mathrm{~m}$ ) $40-50 \%$ was attributed to the top $250 \mathrm{~m}$ and $70-80 \%$ to the top $500 \mathrm{~m}$ (Table 1 ). Therefore, the major transport took place in the upper $500 \mathrm{~m}$, with a tendency of slightly larger transport fraction in the upper ocean at $5^{\circ} 30^{\prime} \mathrm{S}$. On both sections we observed a reversal of the flow field at the offshore edge of the NBUC (Figs 6,7). The transport 


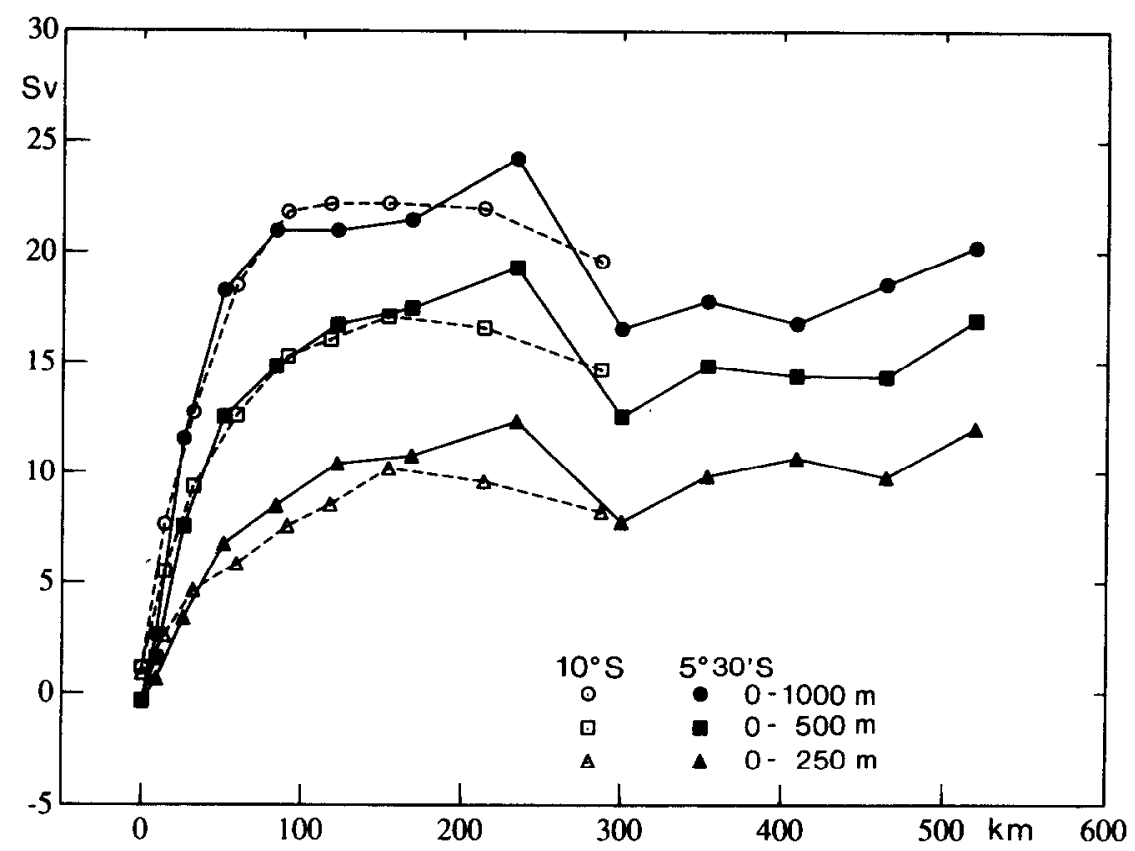

Fig. 6. Cumulative geostrophic northward transport relative to $\sigma_{1}=32.15 \mathrm{~kg} \mathrm{~m}^{-3}$ in Sv in November 1992 at $5^{\circ} 30^{\prime} \mathrm{S}$ (solid symbols) and $10^{\circ} \mathrm{S}$ (open symbols) for the layers $0-250 \mathrm{~m}$ (triangles) 0-500 $\mathrm{m}$ (squares) and 0-1000 $\mathrm{m}$ (dots) plotted versus offshelf distance.

associated with this counter flow was about $2 \mathrm{~Sv}(0-1000 \mathrm{~m})$; from the edge of the NBUC out to $300 \mathrm{~km}$ offshore the continental shelf.

During Meteor cruise 14 in October 1990 two XBT (760 m deep) sections were made south of $5^{\circ} \mathrm{S}$, at about $33^{\circ} \mathrm{W}$ and at about $9^{\circ} \mathrm{S}$ (Fig. 1), as no time was available for CID casts. Geostrophic transport estimates were attempted from these two sections using salinities of the Levitus (1982) summer data set (August, September, October) from two neighbouring $1 \times 1$ degree squares in combination with the measured XBT temperatures. The geostrophic computation was made relative to $700 \mathrm{~m}$ depth, the largest depth possible. The velocities from the XBTs with Levitus salinities led to a velocity field which was not comparable to the velocity distribution from the VM-ADCP. It had to be concluded that a combination of XBTs (reaching $760 \mathrm{~m}$ ) and Levitus salinities is not usable to investigate the velocities and transports in the horizontally variable region of the NBUC without any further adjustments.

\section{BOX TRANSPORTS}

Plots of the mean velocity field (Fig. 7a,b) illustrate the characteristic structures of the NBUC: the intense currents following the $200 \mathrm{~m}$ depth contour (Fig. $7 \mathrm{~b}$ ) and the reduced current amplitude in the near surface layer (Fig. 7a). It is interesting to note that the flow at $10^{\circ} \mathrm{S}$ turned northward with increasing distance from the topography, leading to a convergent flow. In the upper $50 \mathrm{~m}$ at $32^{\circ} \mathrm{W}$, between $8^{\circ} \mathrm{S}$ and $9^{\circ} \mathrm{S}$, the flow was to the east. This is the region where the SECC should be located, and the eastward flow could be the signature of this current. On the diagonal section between $5^{\circ} \mathrm{S}$ and $6^{\circ} 30^{\prime} \mathrm{S}$ at $150-200 \mathrm{~m}$ 

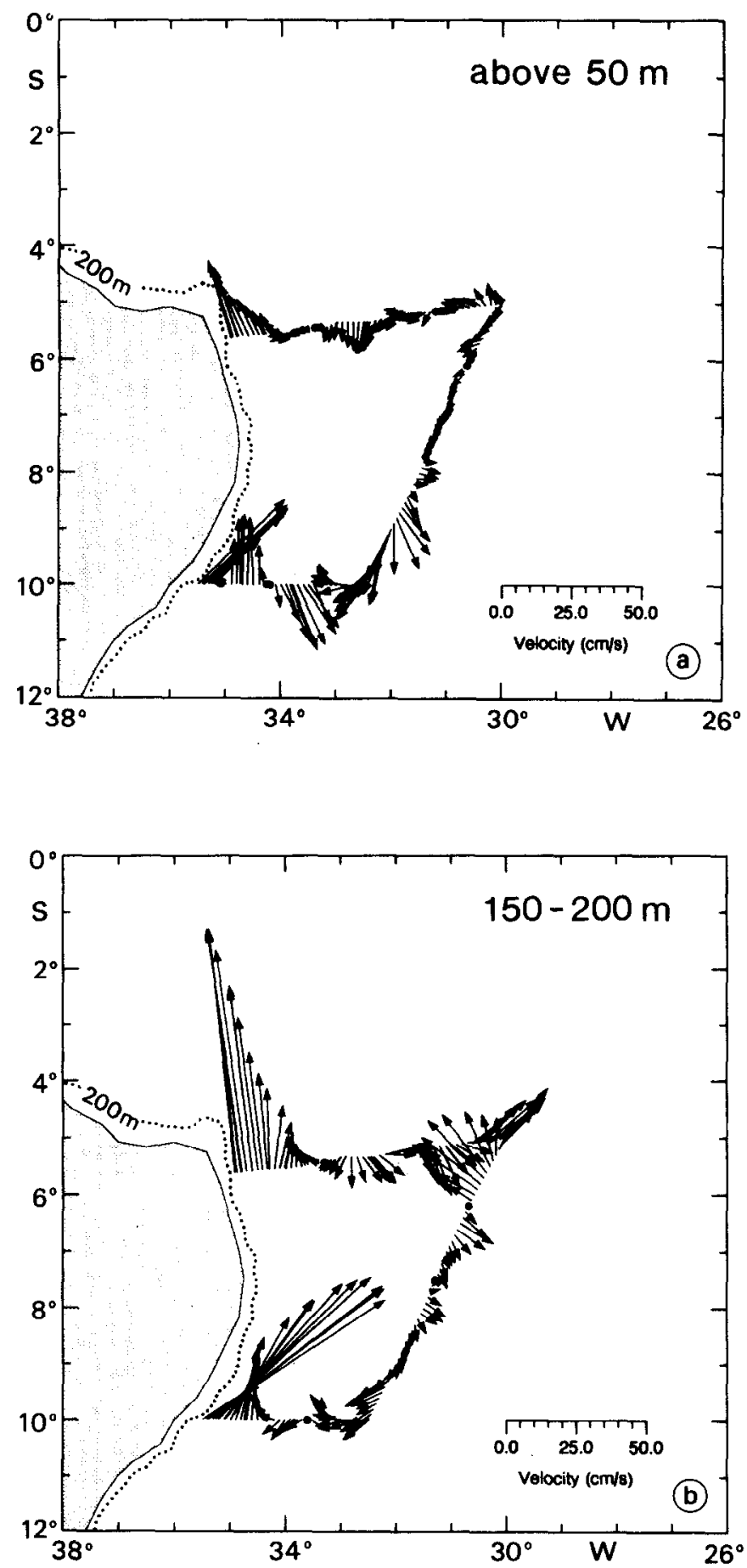

Fig. 7. Mean velocity for the layers (a) above $50 \mathrm{~m}$ and (b) 150-200 $\mathrm{m}$ with the same scale in velocity arrows in November 1992 from VM-ADCP data smoothed by a Gaussian weighting function. Included are the $200 \mathrm{~m}$ depth contours. 
depth, the flow was to the northwest and at the eastern end of the $5^{\circ} 30^{\prime} \mathrm{S}$ section it was to the northeast. This might be a contribution from the SECC to the South Equatorial Undercurrent (SEUC), normally found between $3^{\circ} \mathrm{S}$ and $5^{\circ} \mathrm{S}$. Subsurface velocity enhancement (Fig. 7) supports the interpretation that this might be some contribution to the SEUC.

Transport budgets for the entire box in November 1992 were calculated by using VMADCP, IADCP and geostrophy relative to $\sigma_{1}=32.15 \mathrm{~kg} \mathrm{~m}^{-3}$ (Table 2). The transports 0 $100 \mathrm{~m}$ and $0-250 \mathrm{~m}$ of the VM-ADCP and the IADCP agree well for the zonal sections at $5^{\circ} 30^{\prime} \mathrm{S}$ and $10^{\circ} \mathrm{S}$, but in part this is caused by the fact that the IADCP was adjusted to the VM-ADCP for all stations west of $34^{\circ} \mathrm{W}$ at the $5^{\circ} 30^{\prime} \mathrm{S}$ section and all stations along $10^{\circ} \mathrm{S}$. At $31^{\circ} \mathrm{W}$ no $\mathrm{ADCP}$ transport is given, as the station spacing of about $120 \mathrm{~km}$ is too large to estimate reliable transports from the single point profiles without any information on the flow field in between. No correlation was found between neighbouring stations except that all of the profiles showed weak currents in the depth layer $400-700 \mathrm{~m}$. Information on the flow field between the stations is contained only in the density signature used for geostrophic computations. On the other hand, the use of a reference depth chosen from the general water mass distribution did not always fit the zero velocity found in direct

Table 2. VM-ADCP, lowered-ADCP, geostrophic (relative to $\sigma_{1}=32.15 \mathrm{~kg} \mathrm{~m}^{3}$ with Ekman component in brackets) geostrophic plus Ekman, and adjusted geostrophic transports (to the directly measured 1000-1100 in velocities at 5'30'S and 400-700 $\mathrm{m}$ at $31^{\circ} \mathrm{W}$ ) at (a) about $5^{\circ} 30^{\prime} \mathrm{S}$, (b) about $31^{\circ} \mathrm{W}$ and (c) $10^{\circ} \mathrm{S}$ in November 1992 for the entire sections. Positive transport is into the box (south at $5^{\circ} 30^{\prime} \mathrm{S}$, northwest at $31^{\circ} \mathrm{W}$ and north at $10^{\circ} \mathrm{S}$ )

\begin{tabular}{|c|c|c|c|c|c|}
\hline Depth layer & VM-ADCP & Lowered-ADCP & $\begin{array}{c}\text { Geostrophy } \\
\text { (Ekman) }\end{array}$ & $\begin{array}{l}\text { Geostrophy } \\
\text { plus Ekman }\end{array}$ & $\begin{array}{l}\text { Adjusted } \\
\text { geostrophy }\end{array}$ \\
\hline \multicolumn{6}{|l|}{ (a) $5^{\circ} 30^{\prime} \mathrm{S}$} \\
\hline $0-100 \mathrm{~m}$ & -1.4 & -1.5 & $-3.8(3.0)$ & -0.8 & -4.0 \\
\hline $0-250 \mathrm{~m}$ & -7.9 & -8.4 & $-12.0(3.0)$ & -9.0 & -12.6 \\
\hline $0-500 \mathrm{~m}$ & - & -12.8 & $-17.0(3.0)$ & $-[4.0$ & -18.1 \\
\hline$(1-1000 \mathrm{~m}$ & - & -19.6 & $-20.2(3.0)$ & -17.2 & -22.5 \\
\hline \multicolumn{6}{|l|}{ (b) $31^{\circ} \mathrm{W}$} \\
\hline $0-100 \mathrm{~m}$ & -0.7 & $*$ & $3.5(0.1)$ & 3.6 & 3.0 \\
\hline $0-250 \mathrm{~m}$ & 0.0 & $*$ & $6.9(0.1)$ & 7.0 & 5.0 \\
\hline $0-500 \mathrm{~m}$ & - & $*$ & $6.8(0.1)$ & 6.9 & 3.1 \\
\hline $0-1000 \mathrm{~m}$ & - & $*$ & $6.6(0.1)$ & 6.7 & -0.9 \\
\hline \multicolumn{6}{|l|}{ (c) $10^{\circ} \mathrm{S}$} \\
\hline $0-100 \mathrm{~m}$ & 1.5 & 1.6 & $1.9(-0.7)$ & 1.2 & 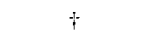 \\
\hline $0-250 \mathrm{~m}$ & 7.2 & 7.4 & $7.9(-0.7)$ & 7.2 & $\frac{\hbar}{\dagger}$ \\
\hline $0-500 \mathrm{~m}$ & - & 16.8 & $14.9(-0.7)$ & 14.2 & $\dot{t}$ \\
\hline $0-1000 \mathrm{~m}$ & - & (23.8安) & $19.9(-0.7)$ & 19.2 & $\dot{t}$ \\
\hline \multicolumn{6}{|l|}{ (d) total box } \\
\hline $0-100 \mathrm{~m}$ & -0.6 & - & $1.6(2.4)$ & 4.0 & - \\
\hline $0250 \mathrm{~m}$ & -0.7 & & $2.8(2.4)$ & 5.2 & \\
\hline $0-500 \mathrm{~m}$ & - & - & $4.7(2.4)$ & 7.1 & $\ldots$ \\
\hline $0-1000 \mathrm{~m}$ & - & - & $6.3(2.4)$ & 8.7 & - \\
\hline
\end{tabular}

* Station spacing of $120 \mathrm{~km}$ too large to estimate reliable transports.

$\dagger$ †ADCP showed too large velocities below $500 \mathrm{~m}$ on eastern side, no adjustment possible.

4 Below $500 \mathrm{~m}$ from coastal profile to flow reversal. 
velocity estimates from the IADCP. The major difference is a geostrophic inflow of $6.9 \mathrm{~Sv}$ from the east across $31^{\circ} \mathrm{W}$ in the upper $250 \mathrm{~m}$, while the deeper layers have no net contribution in the geostrophic calculations. Along the same section the VM-ADCP transports show no net inflow in the upper $250 \mathrm{~m}$.

Another significant difference between geostrophic and direct current measurement transports is evident for the upper layers, 0-100 $\mathrm{m}$ depth and $0-250 \mathrm{~m}$ depth, at $5^{\circ} 30^{\prime} \mathrm{S}$. There, the transport values from the VM-ADCP and the IADCP are smaller than the geostrophic transports (Fig. 8a). The same is true of the $10^{\circ} \mathrm{S}$ section in November 1992 (Fig. 8b), with somewhat smaller differences compared to the $5^{\circ} 30^{\prime} \mathrm{S}$ section.

For the entire box the imbalance in the upper $250 \mathrm{~m}$ is $0.7 \mathrm{~Sv}$ outflow from the VMADCP measurements and $2.8 \mathrm{~Sv}$ inflow from the geostrophic computations. This imbalance is surprisingly low considering that the survey was completed within seven days and might therefore have been non-synoptic. The box is also not completely closed and some water might escape between the coast and the western end of the zonal sections. For the deeper layer the imbalance can be computed only for the geostrophic transport. The imbalance in the geostrophy for the upper $1000 \mathrm{~m}$ is an inflow of $6.3 \mathrm{~Sv}$ without adjustment to the ADCP and if the Ekman component is not taken into account.

The upper layer transports for October 1990 (Table 3) were based on VM-ADCP measurements and geostrophy relative to $\sigma_{1}=32.15 \mathrm{~kg} \mathrm{~m}^{-3}$ (only at $5^{\circ} 30^{\prime} \mathrm{S}$ ). The transport for the $0-100 \mathrm{~m}$ depth layer is composed of $1.1 \mathrm{~Sv}$ entering the box from the east across $33^{\circ} \mathrm{W}, 1.8 \mathrm{~Sv}$ leaving the box across $5^{\circ} 30^{\prime} \mathrm{S}$, and $3.8 \mathrm{~Sv}$ entering across $9^{\circ} \mathrm{S}$. This leads to the imbalance of $3.1 \mathrm{~Sv}$ inflow for the upper $100 \mathrm{~m}$ of the box. In the upper $200 \mathrm{~m}, 4.2 \mathrm{~Sv}$ enter the box from the east across $33^{\circ} \mathrm{W}$ and from the south with $10.7 \mathrm{~Sv}$ across $9^{\circ} \mathrm{S}$. An outflow of $8.1 \mathrm{~Sv}$ left the box to the north across $5^{\circ} 30^{\prime} \mathrm{S}$ and the resulting imbalance of the box transport was an inflow of $6.8 \mathrm{~Sv}$. The transport uncertainty was estimated to be of the order of $3 \mathrm{~Sv}$ for the upper $200 \mathrm{~m}$ being a factor of 2 smaller than the imbalance. At $5^{\circ} 30^{\prime} \mathrm{S}$ the transport estimate from the VM-ADCP compares well with the geostrophic transport (Table 3). It remains an open question regarding what causes the large transport imbalance. One reason might be that the measurements of the box extended over 4.5 days and were therefore non-synoptic. Another reason of course might be the Ekman flow, with the question whether the horizontal transport balance has to be zero in a region where there is a large Ekman convergence and associated downwelling. The choice of depth layers instead of isopycnals as transport boundaries might lead to imbalances. Onshelf flow was not measured and it could possibly contribute as well.

\section{EKMAN LAYER}

A large part of the differences between the direct transports and the geostrophic transports can be explained by the Ekman transport. This flow component is included in the direct measurements but not in the geostrophic transports. Ekman transports across the three sections of the box were calculated after Stramma and Isemer (1988) using the pseudo-windstress values of the area (Servain and Lukas, 1991). From this data set mean November stresses averaged over the years $1985-1989$ were available on a $2^{\circ} \times 2^{\circ}$ grid. The resulting Ekman transports (Table 2, in brackets) are 3.0 Sv to the south across the entire $5^{\circ} 30^{\prime} \mathrm{S}$-section, $0.7 \mathrm{~Sv}$ to the south across the $10^{\circ} \mathrm{S}$ section and negligible transport $(0.1 \mathrm{~Sv})$ perpendicular to the diagonal section at about $31^{\circ} \mathrm{W}$, because the latter is oriented along the direction of the Ekman flow. 
The combined geostrophic and Ekman transport compares well with the direct current observations. The remaining difference at $5^{\circ} 30^{\prime} \mathrm{S}$ of $1 \mathrm{~Sv}$ is well within the accuracy bound of $\pm 2 \mathrm{~Sv}$. At $10^{\circ} \mathrm{S}$ the combined geostrophic and Ekman transports were in agreement (less than $0.2 \mathrm{~Sv}$ difference) with the direct estimates of the upper $250 \mathrm{~m}$. How much of the observed differences might be attributed to variability of the Ekman transport was estimated from actual ship winds. The Ekman transport across $5^{\circ} 30^{\prime} \mathrm{S}$ is $2.2 \mathrm{~Sv}$ compared to $3.0 \mathrm{~Sv}$ from the monthly mean winds and across $10^{\circ} \mathrm{S} 1.1 \mathrm{~Sv}$ southward compared to 0.7
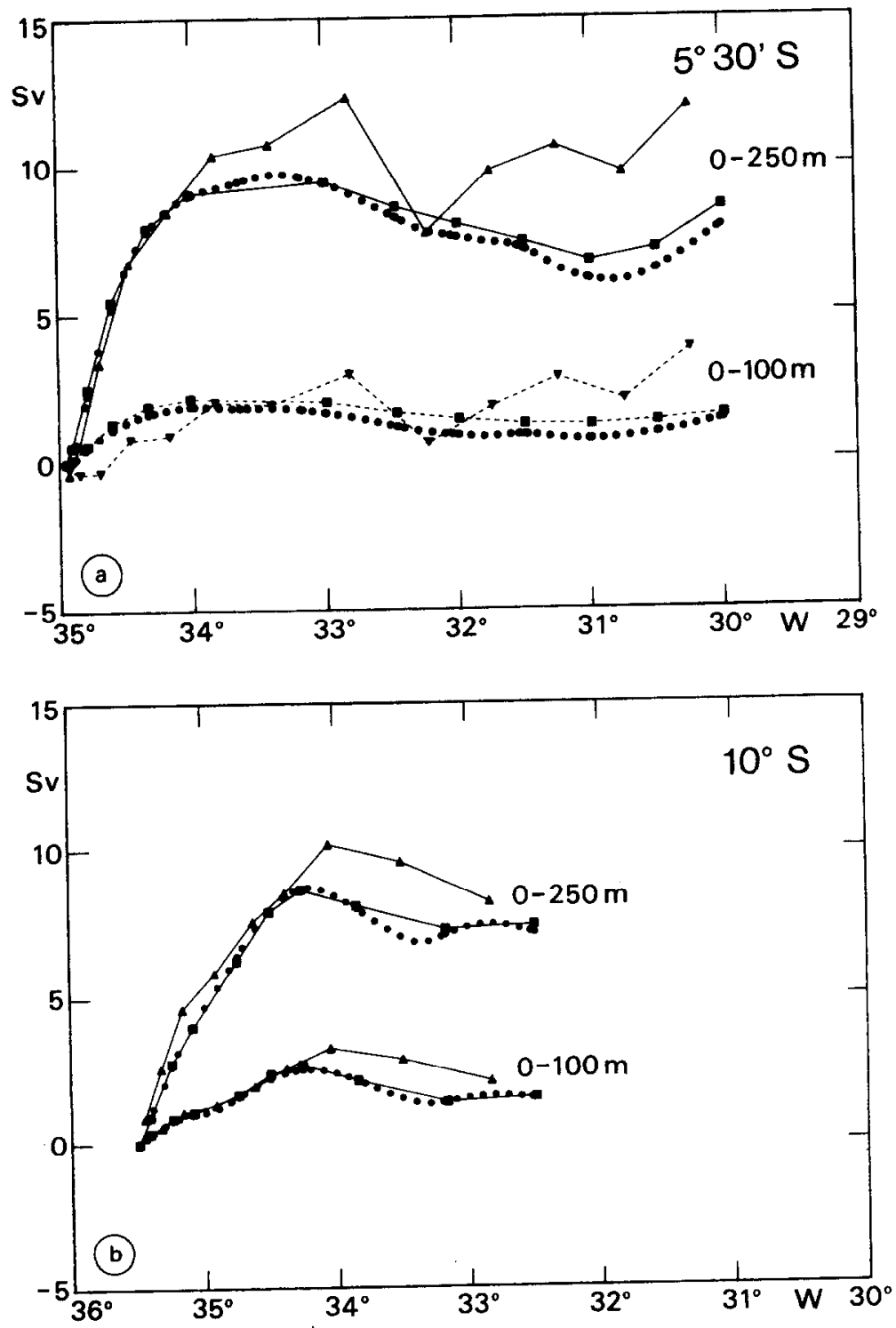

Fig. 8. Cumulative northward transport in Sv at (a) $5^{\circ} 30^{\prime} \mathrm{S}$ and (b) $10^{\circ} \mathrm{S}$ in November 1992 for the layer $0-100 \mathrm{~m}$ and $0-250 \mathrm{~m}$ for VM-ADCP (dots), 1ADCP (squares) and geostrophic transport I elative to $\sigma_{1}-32.15 \mathrm{~kg} \mathrm{~m}^{-3}$ (triangles). 
$\mathrm{Sv}$ from the mean wind field. Therefore, a variability of about $1 \mathrm{~Sv}$ is possible just from variability in the wind data taken to compute the Ekman transport.

\section{METHOD COMPARISON}

From the direct current observations close to the continental shelf at $5^{\circ} 30^{\prime} \mathrm{S}$ (Fig. 4) a level of no motion is hard to detect, but a layer of low vertical shear and small horizontal variability is found roughly between $1000 \mathrm{~m}$ and $1100 \mathrm{~m}$. Combined Pegasus and lADCPvelocities averaged over this layer (Fig. 9 a) vary by $\pm 9 \mathrm{~cm} \mathrm{~s}^{-1}$ following a smooth wavelike structure with about $200 \mathrm{~km}$ wavelength. A reference velocity was then determined for the mean position of each geostrophic station pair by fitting a cubic spline through the direct observations. Where Pegasus stations were available the Pegasus velocities were used; otherwise the IADCP velocities were used. An immediate result (Fig. 9a) is that the geostrophic velocities with the reference level of $\sigma_{1}=32.15 \mathrm{~kg} \mathrm{~m}^{-3}$ compare much better to the direct velocities than the velocities relative to density $\sigma_{4}=45.90 \mathrm{~kg} \mathrm{~m}^{-3}$. The latter was found to be a good reference for the deep circulation (Rhcin et al., 1994). In addition the mean velocity of the entire upper ocean from $10 \mathrm{~m}$ to $1000 \mathrm{~m}$ is presented (Fig. $9 \mathrm{~b}$ ). This figure clearly shows the influence of the NBUC on the mean velocity and the good agreement between the direct measurements and geostrophic calculations relative to $\sigma_{1}=$ $32.15 \mathrm{~kg} \mathrm{~m}^{-3}$.

Adjusting the geostrophic currents to mean speeds in the $1000-1100 \mathrm{~m}$ layer (see above) results in a strong similarity of the NBUC in magnitude and horizontal dimension between direct and geostrophic currents. Core velocities of more that $80 \mathrm{~cm} \mathrm{~s}^{-1}$ are found again below the $150 \mathrm{~m}$ depth at which the current extends out to $33^{\circ} 30^{\prime} \mathrm{W}$. Below that depth the width of the current decreases, with a weak return flow at its eastern flank. Obvious differences between the two measurements exist in the top $100 \mathrm{~m}$ where the geostrophic shear almost vanishes, whereas the directly measured currents show stronger shear. This difference could be due to the absence of the Ekman velocities in the geostrophic

Table 3. VM-ADCP and geostrophic (relative to $\sigma_{1}=32.15 \mathrm{~kg} \mathrm{~m}^{-3}$ at $5^{\circ} 30^{\prime} \mathrm{S}$ ) transports at (a) about $5^{\circ} 30^{\prime} \mathrm{S},(b)$ about $33^{\circ} \mathrm{W}$ and (c) $9^{\circ} \mathrm{S}$ in October 1990 for the entire sections. Positive transport is into the box (south at $5^{\circ} 30^{\prime} \mathrm{S}$, west at $33^{\circ} \mathrm{W}$ and north at $9^{\circ} \mathrm{S}$ )

\begin{tabular}{lll}
\hline Depth layer $\quad$ VM-ADCP Geostrophy \\
\hline
\end{tabular}

\begin{tabular}{lrc} 
(a) $5^{\circ} 30^{\prime} \mathrm{S}$ & & \\
$0-100 \mathrm{~m}$ & -1.8 & -1.2 \\
$0-200 \mathrm{~m}$ & -8.1 & -7.9 \\
(b) $33^{\circ} \mathrm{W}$ & & $*$ \\
$0-100 \mathrm{~m}$ & 1.1 & $*$ \\
$0-200 \mathrm{~m}$ & 4.2 & \\
(c) $9^{\circ} \mathrm{S}$ & & $*$ \\
$0-100 \mathrm{~m}$ & 3.8 & $*$ \\
$0-200 \mathrm{~m}$ & 10.7 & \\
\hline
\end{tabular}

${ }^{*}$ no CTDs available 
computations. As can be seen from Table 2 the adjustment of the geostrophic computation at $5^{\circ} 30^{\prime} \mathrm{S}$ leads to only a small increase in transport in the upper $1000 \mathrm{~m}$ from $20.2 \mathrm{~Sv}$ without adjustment to $22.5 \mathrm{~Sv}$ with adjustment. The net flow after adjustment is $19.5 \mathrm{~Sv}$ when the Ekman flow of $3 \mathrm{~Sv}$ is included compared to 19.6 Sv from the IADCP.

At $10^{\circ} \mathrm{S}$ the lowered $\mathrm{ADCP}$ at two eastern stations showed an unrealistic velocity increase below $500 \mathrm{~m}$ depth which was not observed in the geostrophic profiles. The station distance was also large and might have caused aliasing problems. Because of this discrepancy the IADCP transport for the layer $0-1000 \mathrm{~m}$ in Table 2 is given in brackets and includes only the transport from the shelf out to the flow reversal below $500 \mathrm{~m}$ depth. As no Pegasus profiles are available at $10^{\circ} \mathrm{S}$, and due to the inconsistencies in two of the deeper IADCP profiles, no adjustment could be made for the $10^{\circ} \mathrm{S}$ section. The IADCP profiles within the area of the NBUC indicate a low velocity layer near $1150 \mathrm{~m}$ depth. Together with the good resemblance of the geostrophic plus Ekman transport with the direct transport in the upper $250 \mathrm{~m}$ (Table $2 \mathrm{c}$ ), the reference of $\sigma_{1}=32.15 \mathrm{~kg} \mathrm{~m}^{-3}$ should also be appropriate at $10^{\circ} \mathrm{S}$.

A different result was found for the diagonal section connecting the $5^{\circ} 30^{\prime} \mathrm{S}$ and the $10^{\circ} \mathrm{S}$ sections where the station spacing was $1^{\circ}$ latitude. LADCP velocities along this section were fairly weak, showing no coherent structures from one station to the next. This indicates that the station grid was inadequate to resolve the flow structures, and transport estimates from the IADCP had to be regarded as meaningless. As the direct measurements
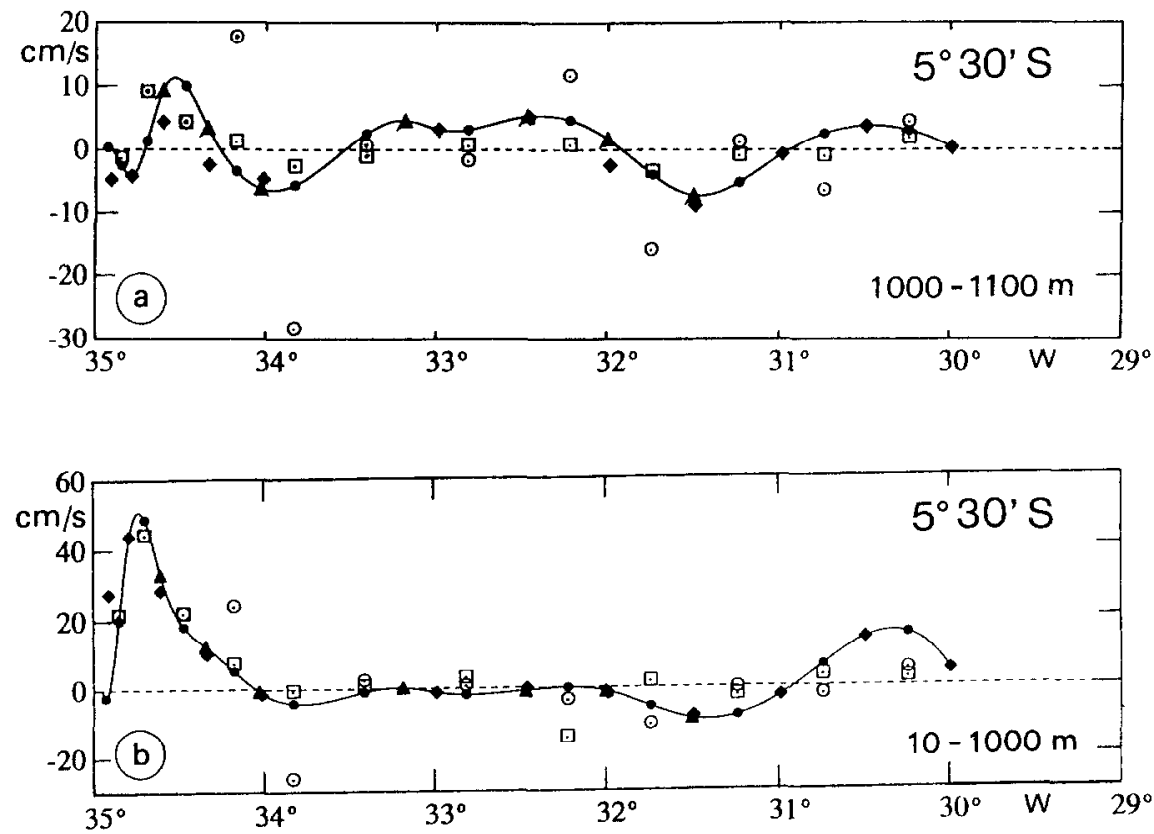

Fig. 9. Mean velocity for the layer (a) $1000-1100 \mathrm{~m}$ depth and (b) $10-1000 \mathrm{~m}$ depth at $5^{\circ} 30^{\prime} \mathrm{S}$ in November 1992 from the 1ADCP measurements (solid diamonds), from Pegasus profiles (solid triangles), the geostrophic computation relative to the density $\sigma_{1}-32.15 \mathrm{~kg} \mathrm{~m}^{-3}$ (open squares) and relative to the density $\sigma_{4}=45.90 \mathrm{~kg} \mathrm{~m}^{-3}$ (open circles). Solid dots on the curve indicate the location of the spline-fitted curve through Pegasus and 1 ADCP mean velocities in the middle of a station pair, where the gcostrophic velocity profile is centered. 
contain no information on the flow field inbetween, a computation of transports from the IADCP would result in a random number and would not be based on physics. The transport has to be taken from the geostrophy, but the transport without adjustment led to an inflow into the box which is not required to balance the transports found at $5^{\circ} 30^{\prime} \mathrm{S}$ and $10^{\circ} \mathrm{S}$ and which is inconsistent with the upper ocean currents measured by the VM-ADCP. Although the IADCP resolution was not adequate for transport calculations, it can provide some information regarding the reference layer. The depth of about $1150 \mathrm{~m}$, typical for the reference $\sigma_{1}=32.15 \mathrm{~kg} \mathrm{~m}^{-3}$, showed relatively large velocities, while at a depth of about $500 \mathrm{~m}$ all IADCP profiles indicated low velocities. Therefore, an adjustment was made for the diagonal section to the IADCP fitted cubic curve through the mean velocity between 400 and $700 \mathrm{~m}$ depth. The adjusted transport (Table 2) for the upper $1000 \mathrm{~m}$ was an outflow of $0.9 \mathrm{~Sv}$ compared to an inflow of $6.6 \mathrm{~Sv}$ into the box without the adjustment. This result might be an indication that for the diagonal section the reference of $\sigma_{1}=32.15 \mathrm{~kg} \mathrm{~m}^{-3}$ is not adequate. It has to be mentioned that a different choice of the layer for the adjustment, such as $500-700 \mathrm{~m}$, leads to transport differences of up to $2.5 \mathrm{~Sv}$, which has to be regarded as a typical error for the adjustment at the diagonal section. Normally it is expected that at a reference level both velocity components become small. Of course in some regions one component might vanish while the other does not. This is the case at about $31^{\circ} \mathrm{W}$ where the meridional flow was small while the zonal flow was not, as can be seen from the direct velocity observations.

As discussed before, the density of $\sigma_{1}=32.15 \mathrm{~kg} \mathrm{~m}^{-3}$ as reference depth seems appropriate for the two zonal sections, and a major difference in transport is found for the diagonal section between the geostrophic flow and the geostrophic flow adjusted to the ADCP. If the transport for the adjusted flow for the diagonal section is combined with the geostrophic flow of the zonal sections (Table 2), the $0-1000 \mathrm{~m}$ imbalance is reduced from $6.3 \mathrm{~Sv}$ to $-1.2 \mathrm{~Sv}$ for geostrophy and to $1.2 \mathrm{~Sv}$ if the Ekman flow is added. This imbalance is lower than the error of $2.5 \mathrm{~Sv}$ associated with the choice of the layer of adjustment.

\section{DISCUSSION}

\section{Comparison to historical data}

The flow field in a closed box off the coast of Brazil in the source region of the NBC was investigated using different observational methods for austral spring in November 1992 and October 1990. The observations showed a strong North Brazil Undercurrent with transports of more than $22 \mathrm{~Sv}$ in the upper $1000 \mathrm{~m}$ in the latitude range $5^{\circ} \mathrm{S}-10^{\circ} \mathrm{S}$. In an evaluation of historical data, Stramma et al. (1990) found a much weaker northward flow of about $5 \mathrm{~Sv}$ at $8^{\circ} \mathrm{S}-9^{\circ} \mathrm{S}$ in February and March from geostrophic computations relative to a density $\sigma_{0}=27.05 \mathrm{~kg} \mathrm{~m}^{-3}$. This density layer was used for the zonal sections and represents the boundary between the Subantarctic Central Water (SACW) and the Antarctic Intermediate Water (AAIW) at depth of about $360-670 \mathrm{~m}$. This layer was appropriate in the Brazil Current region, where Pegasus measurements (Evans and Signorini, 1985) showed the current reversal between the southward Brazil Current and the northward spreading AAIW. In the NBUC region, however, the flow of the NBUC as well as the flow of the AAIW are to the north. Therefore, this density layer used by Stramma et al. (1990), who had no direct velocity observations available, was not appropriate to estimate the total northward transport of the NBUC. This is clearly 
illustrated by Fig. 4b, which shows that the depth of the density $\sigma_{0}=27.05 \mathrm{~kg} \mathrm{~m}^{-3}$ lies in a region of intense northward currents.

According to these findings the transports were recalculated for the zonal sections (except the two Meteor sections from 1926) north of $16^{\circ} \mathrm{S}$ used by Stramma et al. (1990) relative to the density of $\sigma_{1}=32.15 \mathrm{~kg} \mathrm{~m}^{-3}$. In all cases there was a northward transport near the coast with much higher transports compared to the reference used by Stramma $e t$ al. (1990). Hence, also from the historical data base, the NBUC can be described as a western boundary current north of $16^{\circ} \mathrm{S}$, providing the appropriate reference layer is used. Compared to the transports in austral spring (this investigation), the transports from the historical data base, all taken in austral fall, showed smaller transports. None of the fall sections showed NBUC transports larger than $19 \mathrm{~Sv}$ for the layer $0-1000 \mathrm{~m}$. These sections indicated a seasonal cycle between $3 \mathrm{~Sv}$ and $10 \mathrm{~Sv}$. The only section available to Stramma et al. (1990), from the month October at $7^{\circ} 05^{\prime}$ S by R.V. A. Saldanha, had some data problems not noticed before and could not be used. The effect of the two reference layers is illustrated by the R.V. Atlantis section at $12^{\circ} 15^{\prime} \mathrm{S}$. Using $\sigma_{0}=27.05 \mathrm{~kg} \mathrm{~m}^{-3}$ Stramma et al. (1990) obtained $2.2 \mathrm{~Sv}$ southward transport $(0-500 \mathrm{~m})$, whereas with the deep reference the transport was $10.2 \mathrm{~Sv}$ northward. The total $0-1000 \mathrm{~m}$ layer transport was $14.3 \mathrm{~Sv}$. For a cross-check, the Meteor transport at $10^{\circ} \mathrm{S}$ in November 1992 was computed relative to $\sigma_{0}=$ $27.05 \mathrm{~kg} \mathrm{~m}^{-3}$. From the coast to the flow reversal, the $0-500 \mathrm{~m}$ transport was reduced from $16.0 \mathrm{~Sv}$ to $2.3 \mathrm{~Sv}$ and for $0-1000 \mathrm{~m}$ from 22.2 to $1.1 \mathrm{~Sv}$. Summarizing, estimates of the NBUC transports depend strongly on the choice of the appropriate reference layer. Here it is shown that a shallow reference led to incorrect transports suggesting the source of the NBUC further north.

\section{Seasonal signal}

The recalculated transports based on sections from the historical data base of the World Oceanographic Data Center indicate seasonal variability of the NBUC near $10^{\circ} \mathrm{S}$. Larger transports were found in austral spring and smaller values in austral fall. This is in agreement with the evaluation of the WOCE-CME (world ocean circulation experimentcommunity modeling effort) model by Schott and Böning (1991). In their Fig. 9 the transports within the upper $519 \mathrm{~m}$ at $5^{\circ} \mathrm{S}$ between $30^{\circ} \mathrm{W}$ and the coast are $13.2 \mathrm{~Sv}$ on average with the extrema of $20.9 \mathrm{~Sv}$ in August and $8.9 \mathrm{~Sv}$ in February. This is in contrast to the maps by Cochrane et al. (1979), where the NBC appears stronger in February-April and weaker in July-September.

A CTD section was made along $5^{\circ} 30^{\prime} \mathrm{S}$ in June 1991 from R.V. Meteor during cruise M16-3. The section of June 1991 showed the same clear subsurface velocity core at $5^{\circ} \mathrm{S}$, and the undercurrent is a feature of the entire year and not restricted to a part of the year. The transport computed consistently with the other sections of the upper $1000 \mathrm{~m}$ west of the flow reversal was $34.2 \mathrm{~Sv}$ and therefore larger than the transports observed in October 1990 and November 1992. The larger transport for June 1991 was also present in transport estimates from the Pegasus system (U. Send, pers. com.), i.e. not dependent on the choice of a reference layer. The VM-ADCP showed a 0-250 m transport across the entire $5^{\circ} 30^{\prime} \mathrm{S}$ section of $16 \mathrm{~Sv}$ in June 1991, which is also larger than for the two other Meteor realizations reported here of about $8 \mathrm{~Sv}$ (Tables 2 and 3). This finding is consistent with the model result, as the June section is closer to the maximum in August in the CME-model than the October 1990 and November 1992 section. The sections from the historical data set in 
February and March correspond to the minimum transport in February. However, further north at the equator Schott et al. (1993) found only a small seasonal cycle of $\pm 3 \mathrm{~Sv}$ in the upper $600 \mathrm{~m}$ superimposed on $30.5 \mathrm{~Sv}$ annual mean NBC transport. Their calculations based on moored current meter data and ship observations showed the transport maximum in June-August and minimum in northern spring. Therefore, the seasonal signal observed in the "source region of the NBC" seems to be present at the equator, although reduced in magnitude, while the mean transport of the upper $600 \mathrm{~m}$ is much larger at the equator than further south. At the equator a spectral decomposition of the intraseasonal scale variance of the mooring data shows energy maxima at two different periods of about one and two months (Schott et al., 1993). No evidence was found in the literature as to whether these variabilities exist also at $5^{\circ} 30^{\prime} \mathrm{S}-10^{\circ} \mathrm{S}$, but if they do they might influence the amplitude of the seasonal signal as estimated from the sections used.

\section{Final remarks}

In November 1992 there was almost no westward flow at $30^{\circ} \mathrm{W}$ between $10^{\circ} \mathrm{S}$ and $5^{\circ} 30^{\prime} \mathrm{S}$. Therefore, the branch of the South Equatorial Current which feeds the NBUC had to be located south of $10^{\circ} \mathrm{S}$, while additional inflow into the NBC, mainly near the surface, might come from a branch of the SEC north of $5^{\circ} \mathrm{S}$. From the data represented here and the reevaluated sections from the historical data base, it was shown that the NBUC is a permanent feature of the circulation north of $10^{\circ} \mathrm{S}$ and that the origin must be further south. With the weak signal at the sea surface, or even a reversed southward surface flow observed in ship drifts and surface drifters, and with no direct current observations available, the NBUC was difficult to detect, as the major velocities are located in a strong subsurface core.

The formation of the NBUC south of $10^{\circ} \mathrm{S}$ is also present in the WOCE-CME model (Schott and Böning, 1991), where the flow is fed by zonal inflow in the latitude range $11^{\circ}-$ $13^{\circ} \mathrm{S}$. These model results were forced to the seasonally varying Levitus (1982) climatology, and the model domain covered the Atlantic between $65^{\circ} \mathrm{N}$ and $15^{\circ} \mathrm{S}$; therefore the results might be influenced by the boundary conditions at the southern boundary. Nevertheless, the WOCE-CME model describes a NBUC similar to our observations. In a simple model with selected combinations of different basin geometries, wind-stress fields and thermohaline forcing pattern, Onken (1994) described the asymmetries of the western boundary current in the entire Atlantic. Between $8^{\circ} \mathrm{S}$ and $20^{\circ} \mathrm{S}$ the model results differed considerably from the observations of Stramma et al. (1990). At $10^{\circ} \mathrm{S}$ the model required a northward transport of about $21 \mathrm{~Sv}$, and our present observations are in good agreement with the model result.

The NBUC was observed with a subsurface core at about $200 \mathrm{~m}$ depth at $5^{\circ} 30^{\prime} \mathrm{S}$ and $10^{\circ} \mathrm{S}$. Such a subsurface flow, was, to the authors knowledge, not described before from velocity observations, but was proposed by Schott and Böning (1991) evaluating the WOCE-CME model. Defant (1936) discussed the distribution of the salinity maximum at $100-150 \mathrm{~m}$ depth as a southern hemispheric undercurrent along the coast of South America. The subsurface salinity maximum was observed already on a section at about $6^{\circ} \mathrm{S}$ (Stephan 1911 section, Defant 1936) described by Merz (1912).

On a section at $35^{\circ} \mathrm{W}$, off Brazil, carried out in November 1992 during Meteor cruise 22 with Pegasus profilers and IADCP, a subsurface core was observed for the NBUC, while the velocity maximum in some instances moves up to the surface before reaching the 
equator at $44^{\circ} \mathrm{W}$, where the maximum velocity was observed at the surface (Schott et al., 1993). One possible reason for the reduced surface flow between $5^{\circ} 30^{\prime} \mathrm{S}$ and $10^{\circ} \mathrm{S}$ could be the southward component of the Ekman transport. Rough estimates of the Ekman surface velocity with equations given in Pond and Pickard (1978) led to velocities of about $30 \mathrm{~cm}$ $\mathrm{s}^{-1}$ at $5^{\circ} 30^{\prime} \mathrm{S}$ as well as at $10^{\circ} \mathrm{S}$ but with an Ekman depth which was $103 \mathrm{~m}$ at $5^{\circ} 30^{\prime} \mathrm{S}$ and $64 \mathrm{~m}$ at $10^{\circ} \mathrm{S}$ for the November mean wind stress. This Ekman velocity would lead to a considerable reduction of the near surface flow field. However, the observed shear in the near surface layer was larger than indicated by an Ekman flow of such magnitude.

At about $150 \mathrm{~m}$ depth at $5^{\circ} 30^{\prime} \mathrm{S}$ the northward flow, with velocities of more than $10 \mathrm{~cm}$ $\mathrm{s}^{-1}$, extends as a velocity tongue about $70 \mathrm{~km}$ further to the east than the surrounding velocity field. This feature was present in all observations at $5^{\circ} 30^{\prime} \mathrm{S}$, but not at $10^{\circ} \mathrm{S}$. The reason for this feature remains an open question. One possible explanation is that the eastern part of the subsurface core contributes to the South Equatorial Undercurrent.

For the two zonal 1ADCP sections the velocity profiles were correlated from one station to the next, and within the error bounds the transports were the same as for geostrophic calculations. However, the direct current observations were very helpful to determine the appropriate reference layer. They clearly showed that $\sigma_{1}=32.15 \mathrm{~kg} \mathrm{~m}^{-3}$ was preferable compared to $\sigma_{4}=45.90 \mathrm{~kg} \mathrm{~m}^{-3}$, which was superior for the deep flow (Rhein et al., 1995). Although the section-wide transport was about the same for both reference layers, the details were not. In particular the width and transport of the NBUC would have been overestimated by about $20 \mathrm{~km}$ and $5 \mathrm{~Sv}$, respectively, with the deep reference. Furthermore, the direct observations might serve as a reference (level of known motion). For the chosen reference layer $(1000-1100 \mathrm{~m}$ depth $)$ the overall effect was small with the adjusted geostrophic transports at $5^{\circ} 30^{\prime} \mathrm{S}$ about $10 \%$ larger than from geostrophy alone $\left(\sigma_{1}=32.15\right.$ $\mathrm{kg} \mathrm{m}^{-3}$ ). A larger effect (with larger uncertainties) was found at the diagonal section where the adjusted transport strongly reduced the imbalance of the box transport.

Acknowledgements-We thank the captains and crews of the R.V. Meteor for their help, C. Meinke and U. Papenburg for technical assistance, F. Schott for enlightening discussions, O. Plähn for computing the Ekman components and A. Eisele for drafting the figures. Financial support by Deutsche Forschungsgemeinschaft, Bonn and Bundesministerium für Forschung und Technologie, Bonn is gratefully acknowledged.

\section{REFERENCES}

Arnault S. (1987) Tropical Atlantic geostrophic currents and ship drifts. Journal of Geophysical Research, 92 , 5076-5088.

Cochrane J. D., F. J. Kelly Jr and C. R. Olling (1979) Subthermocline countercurrents in the western equatorial Atlantic Ocean. Journal of Physical Oceanography, 9, 724-738.

Defant A. (1936) Stratification and circulation of the Atlantic Ocean: The troposphere, translated by W. J. Emery (1981) Amerind Publishing Co, New Dehli, 113 pp.

Evans D. L. and S. S. Signorini (1985) Vertical structure of the Brazil Current. Nature, 315, 48-50.

Fischer J. and M. Visbeck (1993) Deep velocity profiling with self-contained ADCP's. Journal of Atmospheric and Oceanic Technology, 10, 764-773.

Lcvitus S. (1982) Climatological Atlas of the World Ocean, NOAA Professional paper 13, $173 \mathrm{pp}$

Merz A. (1912) Eine ozeanographische Forschungsreise im Atlantischen Ozean. Verhandlungen des XVIII Deutschen Geographentages zu Innsbruck 1912, Berlin 1912, 82-90.

Molinari R. L. (1982) Observations of eastward currents in the tropical South Atlantic Ocean: $1978-1980$. Journal of Geophysical Research, 87, 9707-9714.

Molinari R. L. (1983) Observations of near-surface currents and temperature in the central and western tropical Atlantic Ocean. Journul of Geophysical Research, 88, 4433-4438. 
Molinari R. L., R. A. Fine and E. Johns (1992) The deep western boundary current in the western tropical North Atlantic Ocean. Deep-Sea Research, 39, 1967-1984.

Onken R. (1994) The asymmetry of Western Boundary Currents in the upper Atlantic Ocean. Journal of Physical Oceanography, 24, 928-948.

Pond S. and G. L. Pickard (1978) Introductory dynamic oceanography, Pergamon Press, Oxford, $241 \mathrm{pP}$

Reid J. L. (1989) On the total geostrophic circulation of the South Atlantic Ocean: Flow patterns, tracers and transports. Progress in Oceanography, 33, 1-92.

Reid J. L. (1994) On the total geostrophic circulation of the North Atlantic Ocean: Flow patterns, tracers and transports. Progress in Oceanography, 23, 149-244.

Rennell J. (1832) An investigation of the currents of the Atlantic Ocean, and of those which prevail between the Indian Ocean and the Atlantic. J. G. \& F. Rivington, London, 299 pp, 2 plates.

Reverdin G. and M. J. McPhaden (1986) Near-surface current and temperature variability observed in the equatorial Atlantic from drifting buoys. Journal of Geophysical Research, 91, 6569-6581.

Rhein M., L. Stramma and U. Send (1995) The Atlantic Deep Western Boundary Current: Water masses and transports near the equator. Journal of Geophysical Research, 100, 2441-2457.

Richardson P. L., G. E. Hufford, R. Limeburger and W. S. Brown (1994) North Brazil Current retroflection eddies. Journal of Geophysical Research, 99, 5081-5093.

Richardson P. L. and D. Walsh (1986) Mapping climatological seasonal variations of surface currents in the tropical Atlantic using ship drifts. Journal of Geophysical Research, 91, 10537-10550.

Schott F. and C. W. Böning (1991) The WOCE model in the western equatorial Atlantic: upper-layer circulation. Journal of Geophysical Research, 96, 6993-7004.

Schott F., J. Fischer, J. Reppin and U. Send (1993) On mean and seasonal currents and transports at the western boundary of the equatorial Atlantic. Journal of Geophysical Research, 98, 14353-14368.

Send U. (1994) The accuracy of current profile measurements-effect of tropical and mid latitude internal waves. Journat of Geophysical Research, 99, 16229-16236.

Servain J. and S. Lukas (1991) Climatic Atlas of the tropical Atlantic wind stress and sea surface temperature. IFREMER report, $133 \mathrm{pp}$.

Spain P. F., D. L. Dorson and H. T. Rossby (1981) PEGASUS: A simple acoustically tracked velocity profiler. Deep-Sea Research, 28, 1553-1567.

Stramma L. (1991) Geostrophic transport of the South Equatorial Current in the Atlantic. Journal of Marine Research, 49, 281-294.

Stramma L., Y. Ikeda and R. G. Peterson (1990) Geostrophic transport in the Brazil Current region north of $20^{\circ}$ S. Deep-Sea Research, 37, 1875-1886

Stramma L. and H. J. Isemer (1988) Seasonal variability of meridional temperature fluxes in the eastern North Atlantic Ocean. Deep-Sea Research, 46, 281-299. 